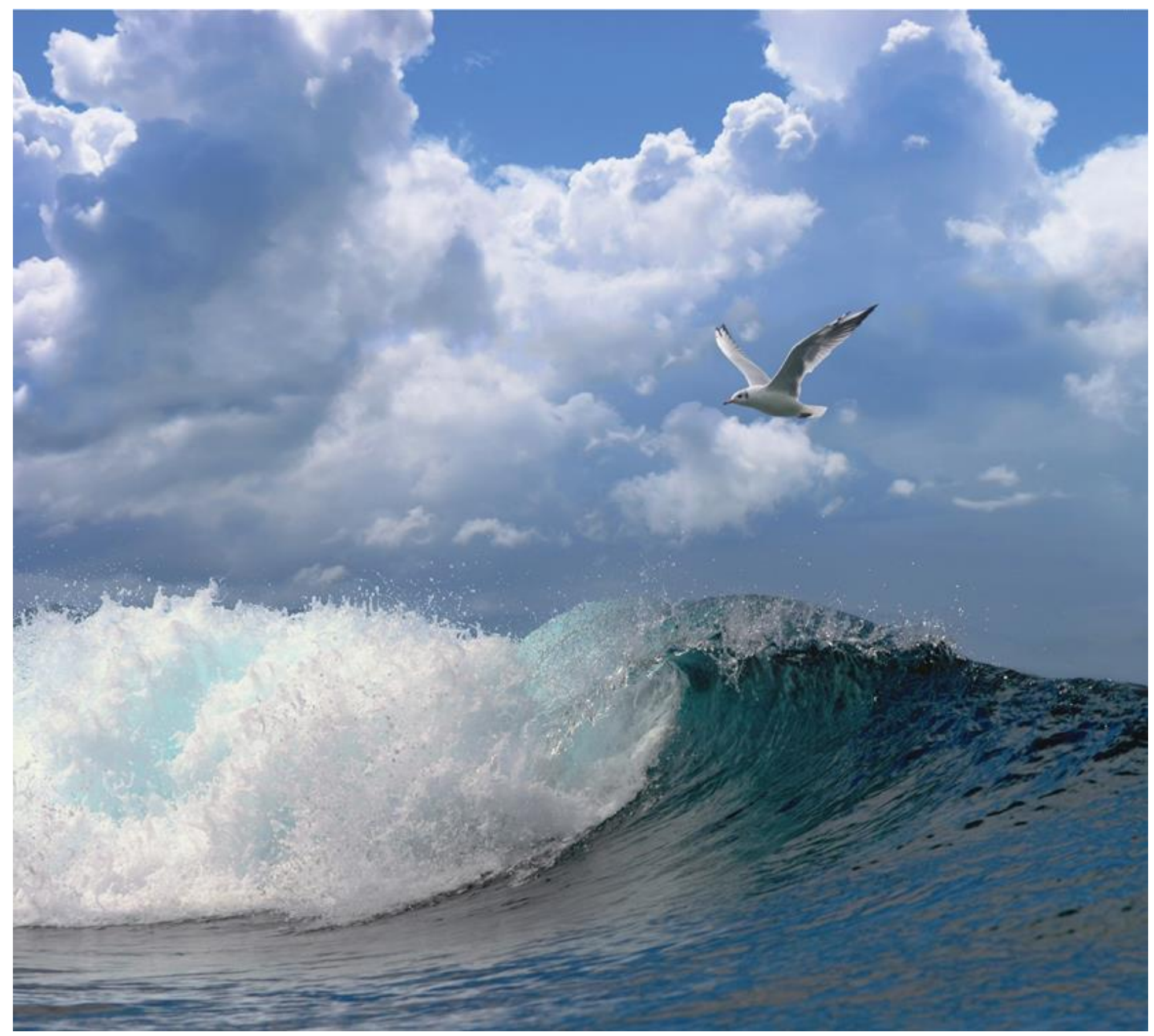

\title{
Passende Beoordeling ten behoeve van experimentele oesterkweek in het litoraal van de Kom van de Oosterschelde
}




\section{Passende Beoordeling ten behoeve van experimentele oesterkweek in het litoraal van de Kom van de Oosterschelde}

Publicatiedatum: 9 december 2016 
Pauline Kamermans, 2016. Passende Beoordeling ten behoeve van experimentele oesterkweek in het litoraal van de Kom van de Oosterschelde; Wageningen Marine Research Wageningen UR (University \& Research centre), Wageningen Marine Research rapport C124/16. 38 blz.

Keywords: oesterteelt, Oosterschelde, aquacultuur.

Opdrachtgever: Nederlandse Oestervereniging

T.a.v.: dhr J. de Rooij

's-Gravenpolderseweg 72

$4462 \mathrm{CH}$ Goes

Wageningen Marine Research Wageningen UR is ISO 9001: 2008 gecertificeerd.

Dit rapport is gratis te downloaden van https://doi.org/10.18174/400928

Wageningen Marine Research verstrekt geen gedrukte exemplaren van rapporten.

\section{(c) 2016 Wageningen Marine Research Wageningen UR}

Wageningen Marine Research, onderdeel van Stichting Wageningen Research KvK nr. 09098104,

IMARES BTW nr. NL 8113.83.696.B16.

Code BIC/SWIFT address: RABONL2U

IBAN code: NL 73 RABO 0373599285
De Directie van Wageningen Marine Research is niet aansprakelijk voor gevolgschade, noch voor schade welke voortvloeit uit toepassingen van de resultaten van werkzaamheden of andere gegevens verkregen van Wageningen Marine Research opdrachtgever vrijwaart Wageningen Marine Research van aanspraken van derden in verband met deze toepassing.

Dit rapport is vervaardigd op verzoek van de opdrachtgever hierboven aangegeven en is zijn eigendom. Niets uit dit rapport mag weergegeven en/of gepubliceerd worden, gefotokopieerd of op enige andere manier gebruikt worden zonder schriftelijke toestemming van de opdrachtgever. 


\section{Inhoud}

$2 \quad$ Te beoordelen activiteit $\quad 7$

$\begin{array}{llr}2.1 & \text { Locatiebepaling } & 7\end{array}$

2.2 Beschrijving van het project $\quad 9$

2.2.1 Kweekopstellingen 109

$\begin{array}{lll}2.2 .2 & \text { Markering } & 10\end{array}$

$\begin{array}{ll}2.2 .3 \text { Uitgangsmateriaal } & 10\end{array}$

$\begin{array}{lll}2.2 .4 & \text { Werkwijze } & 11\end{array}$

$3 \quad$ Beleid $r$

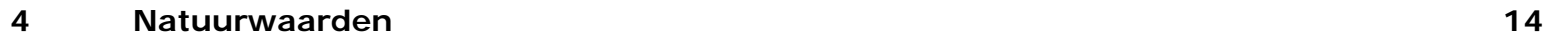

$\begin{array}{lll}4.1 & \text { Beschermde natuurwaarden en kenmerken } & 14\end{array}$

$\begin{array}{lll}4.2 & \text { Relevante beschermde natuurwaarden } & 16\end{array}$

$\begin{array}{llr}5 & \text { Effectenanalyse } & 17\end{array}$

$\begin{array}{lll}5.1 & \text { Verstoring van beschermde soorten } & 17\end{array}$

$\begin{array}{llr}5.2 & \text { Verontreiniging } & 18\end{array}$

$\begin{array}{lll}5.3 & \text { Verandering dynamiek substraat } & 18\end{array}$

$\begin{array}{ll}5.4 & \text { Verandering soortensamenstelling } \\ 5.5 & 19\end{array}$

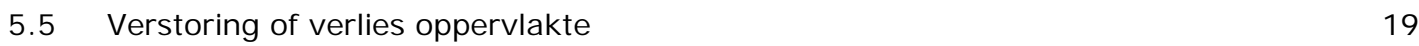

$\begin{array}{lll}5.6 & \text { Vogels } & 20\end{array}$

$\begin{array}{lll}5.7 & \text { Habitatsoorten } & 22\end{array}$

$\begin{array}{llr}6 & \text { Mitigerende maatregelen } & 23\end{array}$

$\begin{array}{llr}7 & \text { Cumulatieve effecten } & 24\end{array}$

8 Conclusie $r 25$

$\begin{array}{lr}\text { Kwaliteitsborging } & 26\end{array}$

$\begin{array}{lr}\text { Literatuur } & 27\end{array}$

$\begin{array}{lr}\text { Verantwoording } & 29\end{array}$

$\begin{array}{lll}\text { Bijlage } 1 & \text { Factsheet triploïde oesters } & 30\end{array}$

Bijlage 2 Begeleiding OesterKweek eXperimenten (BOKX) 32

$\begin{array}{lll}\text { Bijlage } 3 & \text { Voorkomen vogels op locatie } 640 & 33\end{array}$ 


\section{Samenvatting}

Sinds 2010 is aangetoond dat er in de Oosterschelde sprake is van een oester herpes virus waardoor er met name bij de jonge oesters een veel hogere sterfte optreedt. Het virus manifesteert zich bij een watertemperatuur tussen 16 en $18{ }^{\circ} \mathrm{C}$. Het virus is in 2008 in Frankrijk aangetroffen en heeft daar tot grote sterfte van oesters geleid. Inmiddels zijn er aanwijzingen voor toenemende resistentie bij de oesters in Frankrijk. Daarnaast is er voor de oesterkweek een probleem met oesterboorders die in de Oosterschelde zijn aangetroffen en die daar tot sterfte leiden van de oester op de kweekpercelen.

Om te komen tot herstel van de oesterproductie hebben de Nederlandse Oestervereniging (NOV) en het ministerie van Economische Zaken een plan van aanpak geformuleerd om onder andere met behulp van nieuwe technieken de problemen te beheersen. De nieuwe technieken hebben allemaal betrekking op off-bottom kweek. De experimenten zullen worden begeleid door Wageningen Marine Research met onderzoek naar de effectiviteit en de effecten op de natuur.

Voor deze experimenten met off-bottom technieken dient de gebruikelijke vergunningprocedure voor activiteiten in Natura 2000-gebieden te worden doorlopen. Onderdeel van deze procedure is dat er een Passende Beoordeling wordt uitgevoerd waarin op basis van de best beschikbare kennis en informatie wordt getoetst of de beoogde activiteit geen wezenlijk negatief effect heeft op de instandhoudingsdoelen en daarmee de kernopgaven die in het aanwijzingsbesluit voor het betreffende Natura 2000-gebied zijn geformuleerd.

De activiteiten die gerelateerd zijn aan experimentele oesterkweek op percelen Yerseke Bank 74 en 75 in het litoraal van Kom van de Oosterschelde zijn geanalyseerd wat betreft de effecten op de instandhoudingsdoelstellingen van habitats en beschermde soorten. Ook is ingegaan op mitigerende maatregelen en cumulatieve effecten.

In voorliggende Passende Beoordeling is de beschikbare informatie samengevat. De conclusie is dat er geen significant negatieve effecten worden verwacht van experimentele oesterkweek op de percelen Yerseke Bank 74 en 75 in het litoraal van Kom van de Oosterschelde. Dit geldt zowel voor de Natura 2000-instandhoudingdoelen van habitats en soorten als voor aan de orde zijnde verbeteropgaven voor dit gebied. 


\section{$1 \quad$ Inleiding}

In de kom van de Oosterschelde vindt de kweek van Japanse oesters (Crassostrea gigas) plaats op kweekpercelen op de bodem, voornamelijk beneden laagwater. In totaal is er 1550 ha perceelgrond beschikbaar, maar niet alle percelen zijn in gebruik. De kweek bestaat uit het invangen van oesterbroed met behulp van lege (mossel)schelpen waarop het jonge oesterbroed zich vasthecht. De schelpen worden voor de broedval uitgezaaid op broed-invang percelen en in een tijdbestek van ca 9 12 maanden opgevist en verplaatst naar percelen voor de opkweek. De opbrengst wordt geschat op 3 $\mathrm{mln} \mathrm{kg} \mathrm{oesters} \mathrm{per} \mathrm{jaar.} \mathrm{Dit} \mathrm{correspondeert} \mathrm{met} \mathrm{een} \mathrm{geschatte} \mathrm{bestandsgrootte} \mathrm{van} 10 \mathrm{mln} \mathrm{kg} \mathrm{(Smaal}$ et al., 2013)

Door twee recentelijk opgetreden bedreigingen zijn de oesterkwekers op zoek naar nieuwe kweekmethoden (NOV, 2016; Smaal et al., 2016).

Sinds 2010 komt in de Oosterschelde een oester herpes virus voor waardoor er met name bij de jonge oesters een veel hogere sterfte optreedt. Het virus manifesteert zich bij een watertemperatuur tussen 16 en $18{ }^{\circ} \mathrm{C}$. Het virus is in 2008 in Frankrijk aangetroffen en heeft daar tot grote sterfte geleid. Inmiddels zijn er aanwijzingen voor toenemende resistentie bij de oesters in Frankrijk Kamermans et al., 2013; Dundon et al., 2011).

Daarnaast is er een probleem met oesterboorders die in de Oosterschelde zijn geïntroduceerd, nl. de Japanse oesterboorder Ocinebrellus inornata en de Amerikaanse oesterboorder Urosalpinx cinerea (Fig. 1 en 2). De eerste meldingen van de Japanse oesterboorder dateren van 2007 (Faase \& Ligthart, 2009), maar het is mogelijk dat de slak al langer aanwezig is en niet eerder correct is gedetermineerd (Faase \& Ligthart, 2009). Van de Amerikaanse oesterboorder zijn tot nu toe alleen enkele exemplaren aangetroffen op 1 locatie in de Oosterschelde, namelijk bij Gorishoek.
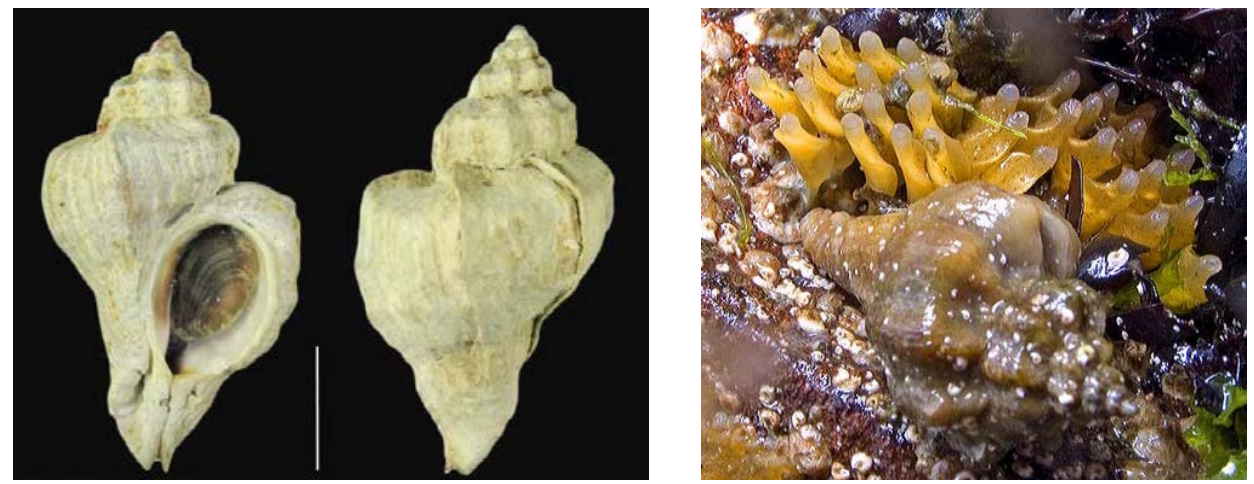

Figuur 1. Ocinebrellus inornatus (foto: L. Schroeder, found at http://www.bily.com). Rechts: ei capsules en slak (Image: http://www.cryptosula.nl).
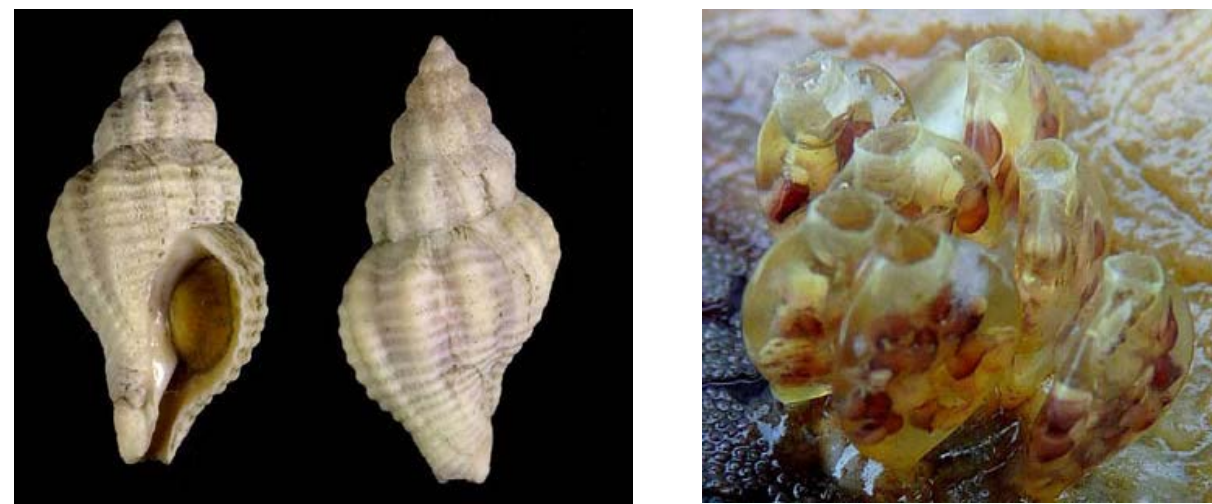

Figuur 2. Urosalpinx cinerea (foto: BISHOGAl Data Base http://shell.kwansei.ac.jp). Rechts: ei capsules met jonge slakjes nabij Gorishoek, The Netherlands (foto. A.H.M. Ligthart (Faasse \& Ligthart 2009). 
De J apanse oesterboorder is in de periode 2007 - 2013 aangetroffen in de oesterputten in Yerseke en nabij Gorishoek. Een recente inventarisatie laat zien dat de slakken nu ook worden aangetroffen in de Kom, de Dortsman, het Prinsenplaatje, de Zandkreek, de Galgenplaat en de Noordelijke tak (van Stralen et al., 2015).

Vanuit de praktijk van de oesterkwekers wordt gemeld dat de overleving van oesterbroed sinds 2013 veel te leiden heeft van het herpesvirus. Verder worden er veel slakken en ook regelmatig ei pakketten aangetroffen op en nabij oesters, en veel schelpen met een boorgat, waardoor van de broedjes die het virus overleven vervolgens weinig terecht komt door predatie door de boorders. De combinatie van beide vijanden leidt nu tot grote problemen in de oesterkweek (Strietman et al., 2016). Om te komen tot herstel van de oesterproductie hebben de Nederlandse Oestervereniging (NOV) en het ministerie van Economische Zaken een plan van aanpak geformuleerd om onder andere met behulp van nieuwe technieken de problemen te beheersen (NOV, 2016; Smaal et al., 2016). De nieuwe technieken bestaan uit off-bottom kweek.

De Oosterschelde is aangewezen als Natura-2000 gebied (Ministerie van LNV, 2009), waarvoor een ontwerp beheerplan (2015 - 2021) is opgesteld (Min IenM, 2015). Het Natura 2000-gebied Oosterschelde omvat de het buitendijks gebied en een aantal aangrenzende binnendijkse gebieden, zoals de inlagen aan de zuidkust van Schouwen. Voor de nieuwe activiteit dient de gebruikelijke vergunningprocedure voor activiteiten in Natura 2000-gebieden te worden doorlopen. Onderdeel van deze procedure is dat er een Passende Beoordeling (verder PB genoemd) wordt uitgevoerd waarin op basis van de best beschikbare kennis en informatie wordt getoetst of de beoogde activiteit geen wezenlijk negatief effect heeft op de instandhoudingsdoelen en daarmee de kernopgaven die in het aanwijzingsbesluit (Ministerie van LNV, 2009) voor het betreffende Natura 2000-gebied zijn geformuleerd.

Voor experimenten in het sublitoraal met zakken in kooien op de bodem of aan longlines in het sublitoraal van de Kom van de Oosterschelde is voor de initiatiefnemer (NOV) door IMARES een Passende Beoordeling opgesteld (Kamermans \& Smaal, 2016). Een NB wet vergunning is verleend (kenmerk DGAN-NB / 16052053). De experimenten worden begeleid met onderzoek naar de effectiviteit en de effecten op de natuur. In aanvulling op experimenten in het sublitoraal van de Kom van de Oosterschelde heeft de NOV het voornemen ook een proef in het litoraal uit te voeren. Dit geeft de kwekers meer inzicht in de voor- en nadelen van het gebruik van verschillende opkweek methoden. Dit betreft zowel ervaring met de techniek als inzicht in de bedrijfseconomische aspecten. Kweek in het litoraal heeft mogelijk een gunstig effect op de vorm van de oesters. Daarnaast kan efficiënter worden gewerkt doordat er niet vanaf een schip gewerkt hoeft te worden. Door proeven uit te voeren met zowel installaties in het sublitoraal als het litoraal van de Kom van de Oosterschelde kan een vergelijking worden gemaakt wat betreft benodigde arbeid van de kwekers en de groeisnelheid, overleving en kwaliteit van de oesters. Voor een goede vergelijking is het noodzakelijk dat alleen de kweekmethode verschillend is (sublitoraal vs. litoraal). Dat betekent zo min mogelijk variatie in locatie (dus niet vergelijken met Kats of Kattendijke) en uitgangmateriaal (zelfde type oesters gebruiken als in sublitoraal). Off-bottom kweek van oesters in het sublitoraal van de Kom van de Oosterschelde is reeds vergund.

Voorliggende PB kan door de NOV worden gebruikt bij de aanvraag, en door het bevoegd gezag (Ministerie van Economische Zaken) bij het opstellen en verlenen van de benodigde vergunning in het kader van de Natuurbeschermingswet 1998. 


\section{Te beoordelen activiteit}

\section{$2.1 \quad$ Locatiebepaling}

Een lid van de Nederlandse Oester Vereniging is voornemens om oesters met nieuwe off-bottom technieken te gaan kweken op percelen Yerseke Bank 74 en 75 in de Oosterschelde (Figuur 3). Dit zijn onverhuurde percelen die worden omringd door verhuurde percelen. In het totaal gaat het om 2 ha benut oppervlak (dit is inclusief werkruimte en een veiligheidszone).

Het gebied Oosterschelde is een onderdeel van het voormalige estuarium van de Schelde. In 1986 is de Oosterschelde van de Noordzee afgesloten door een stormvloedkering, die de getijdenwerking nog in enige mate toelaat. De huidige Oosterschelde bestaat uit een complex geheel van kreken, onder water staande zandbanken, droogvallende slikken en platen en begroeide, periodiek overstroomde schorren. Het gebied vormt, samen met binnendijkse gebieden, een bijzonder rijk leefmilieu voor flora en fauna. Vooral de ondiepe wateren en het intergetijdengebied zijn rijk aan ongewervelden, dat weer dient als voedsel voor vogels en grotere zeedieren. De dagelijks droogvallende slikken en platen van de Oosterschelde zijn van groot internationaal belang voor foeragerende watervogels, met name voor steltlopers, eendachtigen en meeuwen. De oppervlakte aan buitendijks gebied in de Oosterschelde buitendijks bedraagt $351 \mathrm{~km}^{2}$. Daarvan is $112,5 \mathrm{~km}^{2}$ intergetijdengebied. De oppervlakte van Natura 2000 -gebied Oosterschelde (inclusief binnendijkse gebieden) is $366 \mathrm{~km}^{2}$.

Als gevolg van de getijdestromen vinden erosie- en sedimentatieprocessen plaats die resulteren in een wisselend patroon van schorren, slikken en droogvallende platen (het intergetijdengebied), ondiep water en diepe getijdengeulen. In de monding van de Oosterschelde bevinden zich de diepste stoomgeulen die plaatselijk een diepte van 45 meter bereiken. Tussen deze stroomgeulen en in het gebied ten oosten van de Zeelandbrug bevinden zich uitgestrekte gebieden met ondiepe wateren met zandbanken. In het oosten en noorden van het gebied komen grote oppervlakten slikken voor. Binnendijks worden langs de oever een groot aantal karrevelden inlagen en kreekrestanten tot het gebied gerekend. Deze gebieden bestaan voornamelijk uit vochtige graslanden en open water. Het water, het intergetijdengebied en de binnendijks gelegen gebieden vormen tezamen het leefmilieu voor de rijke flora en fauna van het gebied. De grote variatie aan milieutypen in het gebied gaat gepaard met een grote diversiteit aan dier- en plantensoorten. Genoemde variatie aan milieutypen wordt bepaald door factoren als getij, stroming, watertemperatuur, hoogteligging, waterkwaliteit en sedimentsamenstelling. 

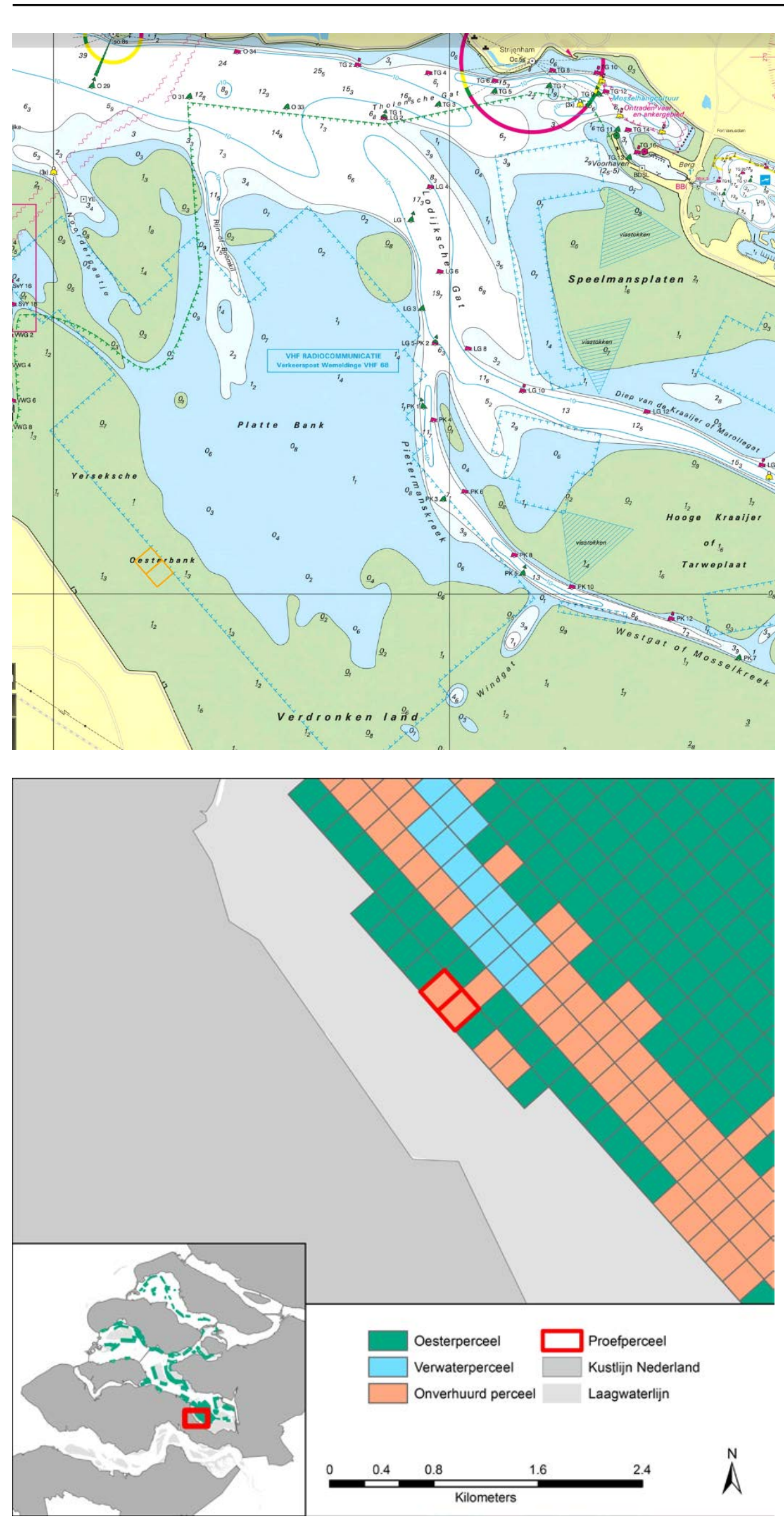

Figuur 3. Litorale oesterpercelen Yerseke Bank 74 en 75 (oranje kaders in bovenste kaart en rode kaders in onderste kaart) in de Kom van de Oosterschelde waar de oesterkweek experimenten gepland zijn. Groen is droogvallend gebied. 
Een specifiek probleem van de Oosterschelde is de zogenaamde 'zandhonger' (Van Maldegem, 2004). Door de bouw van de stormvloedkering is het morfologisch evenwicht van de Oosterschelde verstoord. Het getijvolume is verminderd en de huidige afmetingen van de geulen zijn aan deze afname nog niet aangepast. Zolang de opvulling van de geulen niet is gerealiseerd en de Oosterschelde niet haar nieuwe evenwicht heeft bereikt, zal de Oosterschelde lijden aan zandhonger. Dit heeft tot gevolg dat de platen kleiner worden en daardoor ook het gebied waar steltlopers kunnen foerageren.

\subsection{Beschrijving van het project}

\subsubsection{Kweekopstellingen}

Eén van de te testen systemenop de droogvallende percelen betreft tafels, zoals die ook in Frankrijk worden gebruikt (Fig. 4). Kunststof zakken die zijn gevuld met oesters worden op een frame van betonijzer gelegd. De zakken worden aan het frame vastgemaakt. Een zak heeft een afmeting van ca. $100 \times 50 \mathrm{~cm}\left(0,5 \mathrm{~m}^{2}\right)$. Een tafel is 3 meter lang, $80 \mathrm{~cm}$ breed en $60 \mathrm{~cm}$ hoog en kan 6 zakken dragen. De zakken bevatten bij oogst een verwachtte massa van $12 \mathrm{~kg}$ oesters. Er zullen 500 tafels per perceel worden geplaatst, dus in het totaal 1000 tafels op de percelen YB 74 en YB 75 samen in 15 rijen van $200 \mathrm{~m}$ lang. De afstand tussen de rijen is 5 meter. Daarnaast wordt een ander systeem, namelijk kweek in oestermanden, getest. Deze off-bottom oesterkweeksystemen bestaan uit houten palen, touwen en manden waar de oesters in zitten (Fig. 5). De manden bevatten bij oogst een verwachtte massa van $14 \mathrm{~kg}$ oesters. Er zal 1 rij van 200 meter met 500 manden worden geplaatst.

De installaties worden geplaatst op de percelen. De zakken en mandjes zullen meestal onder water staan, alleen bij laagwaterkentering vallen ze droog. In totaal wordt er maximaal een voorraad gekweekt van $79.000 \mathrm{~kg}$; ten opzichte van een totale geschatte voorraad op de percelen van $10 \mathrm{mln}$ $\mathrm{kg}$ is dat $0,79 \%$. 


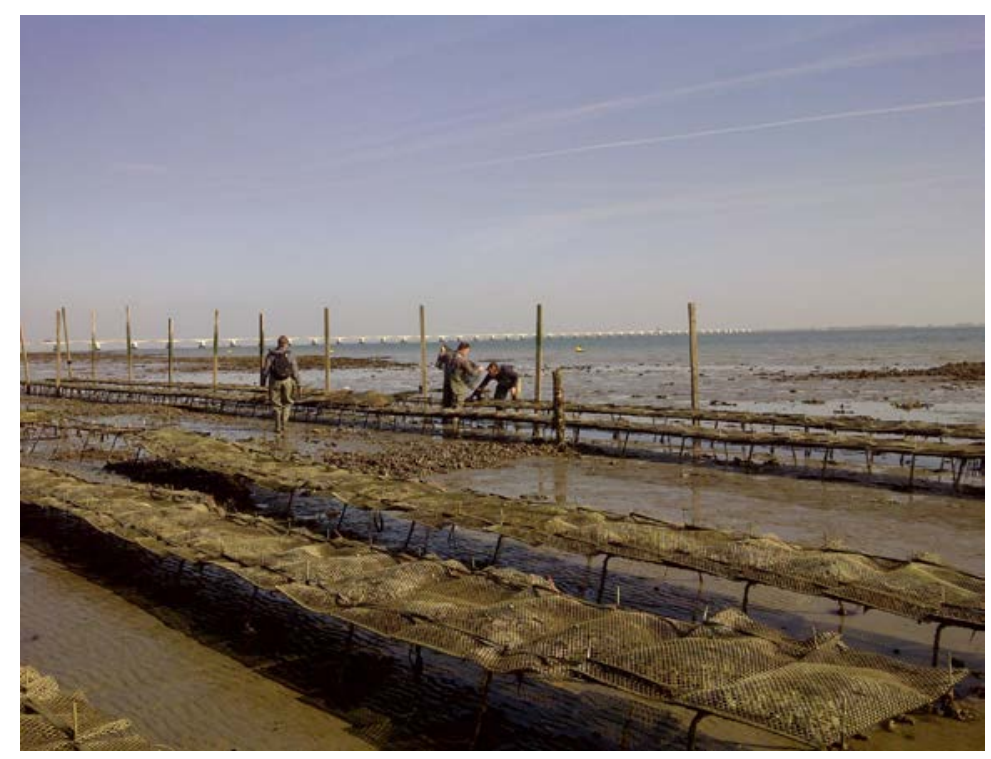

Figuur 4. Voorbeeld van off-bottom oesterkweeksystemen met zakken op tafels voor opkweek tot consumptieformaat.

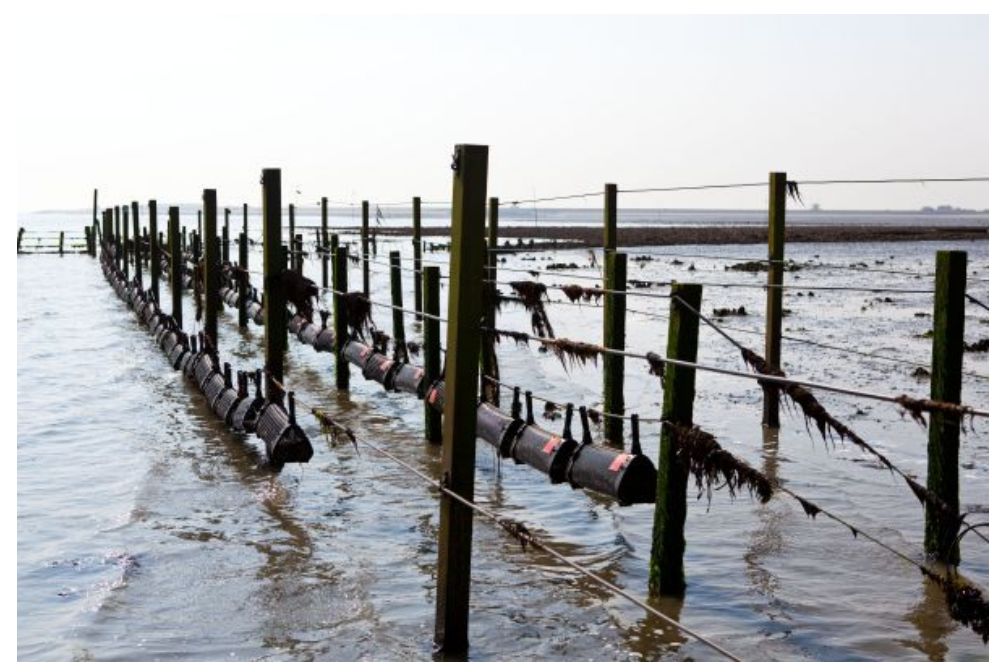

Figuur 5. Voorbeeld van off-bottom oesterkweeksystemen met mandjes aan lijnen voor opkweek tot consumptieformaat.

\subsubsection{Markering}

De installaties zullen worden gemarkeerd met bakens, vergelijkbaar met de markering van percelen en volgens de richtlijnen die door Rijkswaterstaat worden aangegeven. In dit deel van de Kom van de Oosterschelde bevinden zich geen doorgaande vaarwegen. Op de plaats van de installaties is geen scheepvaart, m.u.v. de eigen boot.

\subsubsection{Uitgangsmateriaal}

Als uitgangsmateriaal wordt oesterbroed gebruikt dat op verschillende manieren is verkregen: geproduceerd in een gecertificeerde hatchery, of ingevangen op eigen sublitorale percelen (met lege mossel schelpen of coupelles, Fig. 6), of geraapt op eigen percelen.

De hatchery oesters zijn zowel diploïde als triploïde oesters. Triploïde oesters zijn oesters van dezelfde soort als die nu gekweekt wordt (de Japanse oester Crassostrea gigas), maar dan met drie paar chromosomen in hun cellen in plaats van de normale twee paar in diploïde oesters. De productie van triploïde oesters vindt plaats door een behandeling tijdens de bevruchting in de hatchery. Door de extra set chromosomen zijn triploïde oesters steriel. Omdat geen energie wordt gebruikt voor het 
ontwikkelen van geslachtsorganen en - producten kunnen triploïde oesters sneller groeien (Stanley et al., 1984). In Australie werd na 1 jaar een 1,5x hoger gewicht bereikt bij tripoide oesters (Nell \& Perkins, 2005). Daarnaast bevatten triploïde oesters voldoende vlees van goede kwaliteit in de periode dat andere oesters paaien gewicht verliezen (Nell \& Perkins, 2005; Boudry, 2008). Dit zorgt ervoor dat triploïde oesters ook in de zomer verkocht kunnen worden. Ook zijn triploïde oesters beter resistent tegen stressvolle condities (Garnier-Gere et al., 2002) en vertonen ze een lagere sterfte (Gagnaire et al., 2006). De methode is niet nieuw. In Frankrijk is 30\% van de oesters triploïd (Robert et al., 2012). Er zijn verschillende methoden om triploïde oesters te produceren. Als oesters triploïde zijn gemaakt door fysiologische modificatie ("chemisch geïnduceerd") kan er sprake zijn van onvolledige triploïdie (Lapègue et al., 2008). Een beperkt gedeelte van deze oesters zijn dan terug veranderd in normale diploïde oesters. Als oesters vanuit een tetraploïde en een diploïde ouder zijn gemaakt ("natuurlijk") kunnen ze niet terug veranderen naar diploïde oesters (Guo et al., 1996). Tetraploïde oesters worden in de hatchery gemaakt, genetisch gechecked om te zien of de behandeling succesvol was en daar in quarantaine gehouden in een gecertificeerd quarantaine station en komen dus niet terecht in de Oosterschelde. Voor triploïde nakomelingen is er een kruising van een diploïde en een tetraploïde ouder nodig. Zie ook bijlage 1 (Kamermans, 2015).

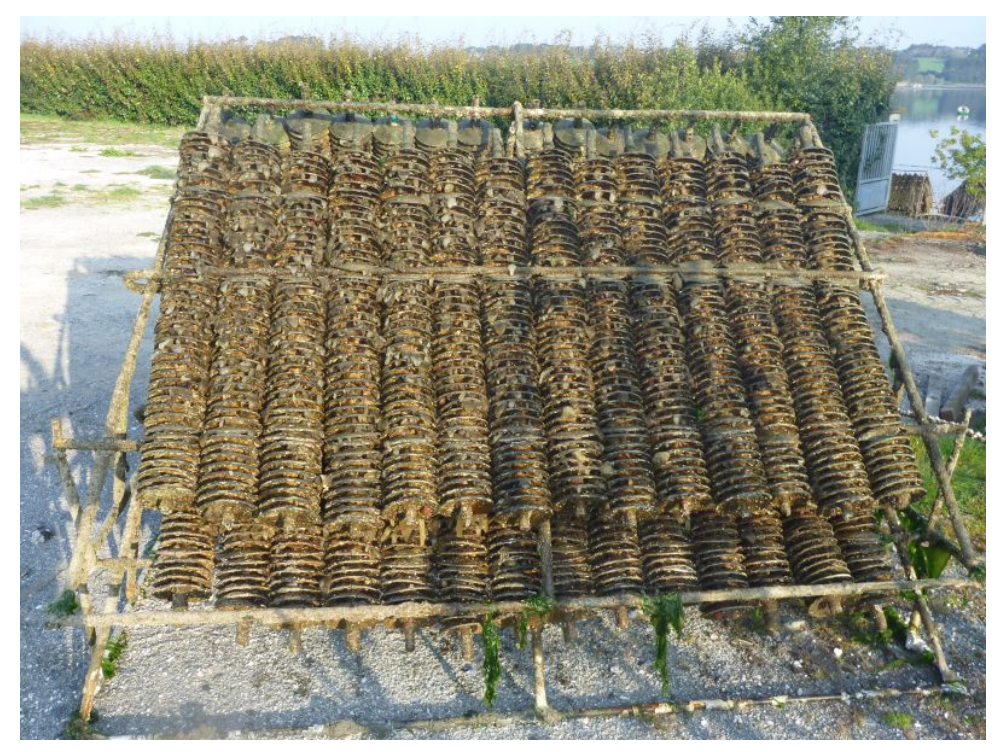

Figuur 6. Voorbeeld van coupelles waarmee oesterbroed wordt ingevangen.

\subsubsection{Werkwijze}

Er wordt vanaf een ondiep schip gewerkt. Dat betekent dat alleen gedurende 1,5 - 2 uur tijdens de laagwaterkentering kan worden gewerkt. Op dat moment vallen de zakken en manden droog. Het vaartuig moet in de buurt van de zakken kunnen komen omdat daarmee de zakken en manden worden aan- en afgevoerd.

De oesters moeten naar verwachting regelmatig worden uitgedund. Tevens zullen de zakken periodiek moeten worden omgekeerd om de aangroei van algen te voorkomen en worden opgeschud om de groeiranden van de oesters te beschadigen, zodat de oester een mooie diep-bolle vorm krijgt. Naar verwachting zukken er in de periode van januari - november één maal per week gedurende 2 - 3 uur (afhankelijk van het aantal zakken) activiteiten zijn. In een deel van de zakken en manden zullen de oesters worden gesorteerd en opnieuw in zakken en manden gedaan. Bij het opnieuw plaatsen, worden de zakken gekeerd en wordt onderhoud gepleegd aan de tafels. De manden en zakken worden voor $1 / 3$ e deel gevuld met kleine oesters. Zodra deze zover zijn opgegroeid dat de helft van de zak/mand is gevuld, wordt een deel overgebracht in een lege zak/mand, zodat de zak/mand opnieuw voor 1 / 3e deel is gevuld. Dat proces herhaalt zich totdat de oesters de consumptiegrootte hebben bereikt. In de periode september tot en met mei, maar met een piek in de periode november tot half december, zullen de oesters die groot genoeg zijn worden geoogst ten behoeve van de verkoop. In de periode november - half december zal er meerdere dagen per week gedurende 2 - 4 uur per dag activiteit zijn. 


\section{Beleid}

\section{Beleidsbesluit schelpdiervisserii}

Door de minister van LNV wordt in het Beleidsbesluit Schelpdiervisserij 2005-2020 (Ministerie van LNV, 2004) ruimte gegeven om te experimenteren met alternatieve en duurzame nieuwe kweekvormen. In het Beleidsbesluit 2005-2020 is met betrekking tot de kweek van schelpdieren (hfdst 4.3) het navolgende opgenomen:

I nitiatieven om ook andere soorten zoals St. J acobsschelpen, Venusschelpen en J apanse oesters te kweken zullen op hun inpasbaarheid binnen de bestaande kaders worden beoordeeld. Op voorhand wordt vanuit een positieve grondhouding naar dit soort initiatieven gekeken. Nieuwe kweekvormen zullen vooraleerst alleen onder experimentele omstandigheden (kleinschalig en begeleid door onderzoek) mogen plaatsvinden

Een experiment met het op een alternatieve wijze kweken van schelpdieren past derhalve in het beleid van de minister van EZ. Voorwaarde is wel dat het duurzaam is, kleinschalig, passend binnen de natuurlijke mogelijkheden en wordt begeleid door onderzoek.

Om de recente problemen in de oesterkweek gezamenlijk het hoofd te kunnen bieden, wordt de komende periode ingezet op maatregelen voor de korte termijn, de middellange en lange termijn zoals beschreven in Plan van Aanpak 'Oester-maatregelen' 2016 - 2018 (NOV, 2016). Om de oesterboorder te ontlopen valt in eerste instantie te denken aan het invangen en kweken in de waterkolom ("off-bottom"). Off-bottom-technieken die hier voor in aanmerking komen zijn:

- Mandjes, die met name in het litoraal kunnen worden gebruikt (kan eventueel ook in het sublitoraal).

- Rekken en tafels, waarop zowel in het litoraal als in het sublitoraal zakken met oesters worden gelegd voor verdere opkweek. Met deze technieken is in de Nederlandse wateren nog weinig ervaring opgedaan, zodat aan de hand van nadere experimenten meer informatie wordt verkregen over de consequenties met betrekking tot onder meer 'lichtinval', 'schaduwwerking' en 'leefgebied en soorten'.

- Staande kweekkooien, die op de bodem in zowel het litoraal als het sublitoraal kunnen worden geplaatst. Ook bij deze technieken kan aan de hand van experimenten meer informatie worden verkregen over de consequenties met betrekking tot onder meer 'lichtinval', 'schaduwwerking' en 'leefgebied en soorten'.

- Hangende kweekkooien, die in het sublitoraal aan longlines zijn bevestigd.

\section{Natura 2000}

De Oosterschelde is op 23 december 2009 door de minister van Landbouw, Natuur en Voedselkwaliteit (LNV, nu Economische Zaken: EZ) definitief aangewezen als Natura 2000-gebied (gebiedsnummer 118: Oosterschelde). Met het oog op deze aanwijzing, dienen activiteiten die als plan of project volgens art. 6:3 van de Habitatrichtlijn (richtlijn 92/43IEEG) kunnen worden aangemerkt, te worden beoordeeld op hun effecten op de instandhoudingdoelstellingen van het gebied.

\section{Provinciaal Sociaal-Economisch Beleidsplan 2009-2012}

In dit plan wordt geconstateerd dat achterblijvende groei van oesters leidt tot verlies van marktaandeel. Verbetering van de kansen voor verschillende vormen van schelpdiercultuur in de Deltawateren vormt één van de prioriteiten voor de Provincie Zeeland.

\section{Ontwerpbeheerplan Deltawateren}

Via dit beheerplan (Van Bentum \& Koolmees, 2014) is de oesterteelt onder specifieke voorwaarden vrijgesteld van de $\mathrm{Nb}$-wet vergunningplicht. De oesterhangcultuur en de experimentele oesterkweek 
met diverse methoden blijft echter een vergunningplichtige activiteit. De oesterkweek vindt plaats op daartoe bestemde oesterpercelen in de Oosterschelde die door het Rijk worden verhuurd.

Vooronderzoek ten behoeve van de passende beoordeling ex artikel 6 lid 3 Habitatrichtlijn

Het project bestaat uit het opkweken van oesters met behulp van mandjes en zakken in het Natura 2000-gebied Oosterschelde, volgens de hierboven omschreven werkwijze. Uitvoering van het onderhavige project betreft een activiteit welke niet direct verband houdt met, of nodig is voor het beheer van het Vogel- en Habitatrichtlijngebied Oosterschelde.

Artikel 6, derde lid, van de Habitatrichtlijn bevat een toetsingskader voor plannen en projecten in of nabij de op grond van de Habitatrichtlijn beschermde gebieden en, via de schakelbepaling van artikel 7 van de Habitatrichtlijn, de op grond van de Vogelrichtlijn beschermde gebieden.

In artikel 6, derde lid, van de Habitatrichtlijn is bepaald dat voor elk plan of project dat niet direct verband houdt met of nodig is voor het beheer van een op grond van deze richtlijn beschermd gebied en afzonderlijk of in combinatie met andere plannen of projecten significante gevolgen kan hebben voor dat gebied, een analyse van de gevolgen voor dat gebied moet worden gemaakt. Hierbij dient rekening te worden gehouden met de instandhoudingsdoelstellingen van dat gebied en geldt dat de bevoegde nationale instanties slechts toestemming voor het betrokken plan of project geven nadat zij op basis van de analyse de zekerheid hebben verkregen dat de natuurlijke kenmerken van het betrokken gebied (met het oog waarop het gebied is aangewezen) niet zullen worden aangetast.

Ten behoeve van deze PB is gekeken naar die soorten en habitattypen welke als kwalificerend zijn aangemerkt met betrekking tot de, binnen de Oosterschelde vallende, Vogel- en Habitatrichtlijngebieden. 


\section{$4 \quad$ Natuurwaarden}

\subsection{Beschermde natuurwaarden en kenmerken}

Het Natura 2000-gebied de Oosterschelde heeft een totaal oppervlak van 36980 ha en bevat zowel een buitendijks als een binnendijks (inlagen, karrevelden, kreekrestanten, eendenkooien) gebied (Ministerie van LNV, 2009). De Oosterschelde is een voormalig estuarium dat in 1986 is afgesloten van de Noordzee door middel van de Oosterscheldekering. Tevens zijn er compartimenteringsdammen aangelegd om het getijvolume te beperken. Door deze Deltawerken is de Oosterschelde veranderd van een estuarium naar een ondiepe baai met zout water en gedempt getij. De droogvallende slikken en platen vormen een belangrijk onderdeel van de getijdennatuur in Zuidwest Nederland.

De huidige Oosterschelde bestaat uit een complex geheel van geulen, onder water staande zandbanken, droogvallende slikken en platen en hoger gelegen schorren. Het gehele aquatische gebied wordt gerekend tot het habitattype H1160 (Grote, ondiepe kreken en baaien, verkorte naam Grote baaien), terwijl de habitattypen buitendijkse schorren (H1330A), slijkgrasvelden (H1320) en zilte pionierbegroeiingen (H1310A) apart zijn aangewezen (J anssen \& Schaminée, 2009). De Oosterschelde is een belangrijk leefgebied voor kustbroedvogels, moerasbroedvogels en doortrekkende en overwinterende watervogels. De Oosterschelde is voor een tweetal habitatsoorten aangewezen: de Gewone zeehond (H1365) en de Noordse woelmuis (H1340).

In het doelendocument (Troost \& Van Hulzen, 2009) is voor de Oosterschelde een aantal kernopgaven geformuleerd:

- Behoud van slikken en platen voor rustende en foeragerende niet-broedende vogels en rustgebieden voor zeehonden;

- Behoud en herstel van schorren en zilte graslanden (buitendijks) met alle successiestadia, zoet-zout overgangen, verscheidenheid in substraat en getijregime en als hoogwatervluchtplaats;

- Behoud en ontwikkeling van kwaliteit binnendijkse brakke gebieden voor Noordse woelmuis en voor broedvogels (Kluut, sterns) en als hoogwatervluchtplaats, overgangs- en trilvenen (veenmosrietlanden) brakke variant van ruigten en zomen (Harig wilgenroosje), schorren en zilte graslanden (binnendijks) en als hoogwatervluchtplaats.

Deze kernopgaven zijn in het aanwijzingsbesluit Oosterschelde (Ministerie van LNV, 2009) vertaald in een aantal instandhoudingsdoelen (Tabel 1).

Tabel 1. Lijst met habitattypen en soorten waarvoor de Oosterschelde is aangewezen, met bijhorende instandhoudingsdoelstellingen. =: behoud doelstelling omvang en kwaliteit. >: uitbereidingsdoelstelling areaal of verbeterdoelstelling kwaliteit (Ministerie van LNV, 2009). *Voor de Gewone zeehond is een regionaal doel gesteld van ten minste 200 exemplaren in het Deltagebied (Ministerie van LNV, 2009).

\begin{tabular}{|c|c|c|c|c|}
\hline & & \multicolumn{3}{|c|}{ Gebiedsdoelstelling } \\
\hline & & 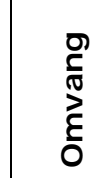 & 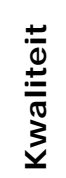 & $\begin{array}{l}\stackrel{0}{+0} \\
\frac{\pi}{3} \\
0 \\
0 \\
0\end{array}$ \\
\hline Code & Habitattypen & & & \\
\hline $\mathrm{H} 1160$ & Grote baaien & $=$ & $>$ & \\
\hline H1310A & Zilte pionierbegroeiingen(zeekraal) & $>$ & $=$ & \\
\hline $\mathrm{H} 1320$ & Slijkgrasvelden & $=$ & $=$ & \\
\hline H1330A & Schorren en zilte graslanden (buitendijks) & $=$ & $=$ & \\
\hline H1330B & Schorren en zilte graslanden (binnendijks) & $>$ & $=$ & \\
\hline
\end{tabular}




\begin{tabular}{|c|c|c|c|c|}
\hline & & \multicolumn{3}{|c|}{ Gebiedsdoelstelling } \\
\hline & & 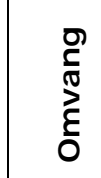 & 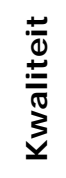 & $\begin{array}{l}\frac{0}{20} \\
\frac{\pi}{5} \\
\frac{0}{0} \\
0\end{array}$ \\
\hline \multirow[t]{2}{*}{ H7140B } & Overgangs- en trilvenen (veenmosrietlanden) & $>$ & $>$ & \\
\hline & Soorten & & & \\
\hline $\mathrm{H} 1340$ & Noordse woelmuis & $>$ & $=$ & $>$ \\
\hline \multirow[t]{2}{*}{ H1365 } & Gewone zeehond & $=$ & $>$ & $>$ \\
\hline & Broedvogels & & & paren \\
\hline A132 & Kluut & $=$ & $=$ & 2000 \\
\hline A137 & Bontbekplevier & $=$ & $=$ & 100 \\
\hline A138 & Strandplevier & $>$ & $>$ & 220 \\
\hline A191 & Grote stern & $=$ & $=$ & 4000 \\
\hline A193 & Visdief & $=$ & $=$ & 6500 \\
\hline A194 & Noordse stern & $=$ & $=$ & 20 \\
\hline \multirow[t]{2}{*}{ A195 } & Dwergstern & $=$ & $=$ & 300 \\
\hline & Niet-broedvogels & & & individuen \\
\hline A004 & Dodaars & $=$ & $=$ & 80 \\
\hline A005 & Fuut & $=$ & $=$ & 370 \\
\hline A007 & Kuifduiker & $=$ & $=$ & 8 \\
\hline A017 & Aalscholver & $=$ & $=$ & 360 \\
\hline A026 & Kleine zilverreiger & $=$ & $=$ & 20 \\
\hline A034 & Lepelaar & $=$ & $=$ & 30 \\
\hline A037 & Kleine zwaan & $=$ & $=$ & \\
\hline A043 & Grauwe gans & $=$ & $=$ & 2300 \\
\hline A045 & Brandgans & $=$ & $=$ & 3100 \\
\hline A046 & Rotgans & $=$ & $=$ & 6300 \\
\hline A048 & Bergeend & $=$ & $=$ & 2900 \\
\hline A050 & Smient & $=$ & $=$ & 12000 \\
\hline A051 & Krakeend & $=$ & $=$ & 130 \\
\hline A052 & Wintertaling & $=$ & $=$ & 1000 \\
\hline A053 & Wilde eend & $=$ & $=$ & 5500 \\
\hline A054 & Pijlstaart & $=$ & $=$ & 730 \\
\hline A056 & Slobeend & $=$ & $=$ & 940 \\
\hline A067 & Brilduiker & $=$ & $=$ & 680 \\
\hline A069 & Middelste zaagbek & $=$ & $=$ & 350 \\
\hline A103 & Slechtvalk & $=$ & $=$ & 10 \\
\hline A125 & Meerkoet & $=$ & $=$ & 1100 \\
\hline A130 & Scholekster & $=$ & $=$ & 24000 \\
\hline A132 & Kluut & $=$ & $=$ & 510 \\
\hline A137 & Bontbekplevier & $=$ & $=$ & 280 \\
\hline A138 & Strandplevier & $=$ & $=$ & 50 \\
\hline A140 & Goudplevier & $=$ & $=$ & 2000 \\
\hline A141 & Zilverplevier & $=$ & $=$ & 4400 \\
\hline A143 & Kanoetstrandloper & $=$ & $=$ & 7700 \\
\hline A144 & Drieteenstrandloper & $=$ & $=$ & 260 \\
\hline A149 & Bonte strandloper & $=$ & $=$ & 14100 \\
\hline A157 & Rosse grutto & $=$ & $=$ & 4200 \\
\hline A160 & Wulp & $=$ & $=$ & 6400 \\
\hline A161 & Zwarte ruiter & $=$ & $=$ & 310 \\
\hline A162 & Tureluur & $=$ & $=$ & 1600 \\
\hline A164 & Groenpootruiter & $=$ & $=$ & 150 \\
\hline A169 & Steenloper & $=$ & $=$ & 580 \\
\hline
\end{tabular}




\subsection{Relevante beschermde natuurwaarden}

Deze paragraaf beschrijft de relevante natuurwaarden met betrekking tot de kweekexperimenten voor oesterteelt in de Oosterschelde. De activiteiten met betrekking tot de kweekexperimenten voor oesterteelt in de Oosterschelde vinden plaats op en nabij bestaande oesterpercelen in het natte deel van het Natura 2000-gebied. De terrestrische habitat typen (H1310A, H1320, H1330A, H1330B en H7140B) worden op voorhand niet beïnvloed door de kweekexperimenten en zijn daarmee niet relevant voor deze PB. Dit geldt ook voor de Noordse woelmuis (H1340), die niet voorkomt in de Kom van de Oosterschelde (Fig. 7).

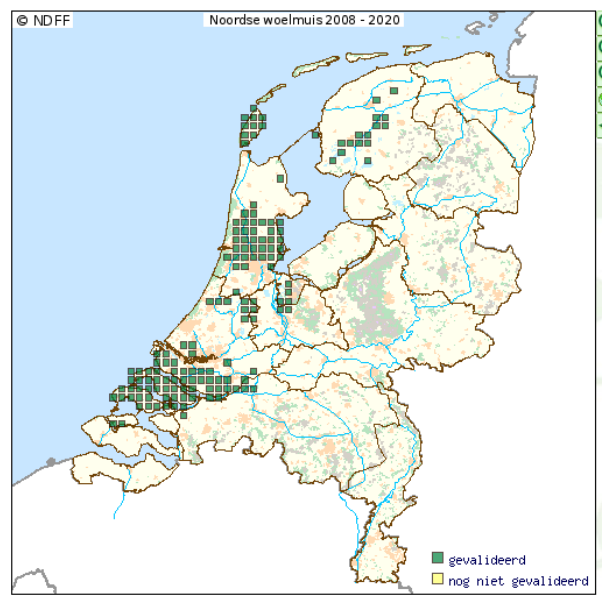

Figuur 7. Verspreiding van de Noordse woelmuis in Nederland (www.telmee.nl).

Het habitattype is $\mathrm{H} 1160$ (Grote baaien), zijnde het habitattype waarbinnen de oesterteelt plaatsvindt, is wel relevant en dus onderwerp van deze PB. Het habitattype is in de Oosterschelde tot stand gekomen door de aanleg van dammen die de zoetwateraanvoer van het oorspronkelijke estuarium beperken. De soortensamenstelling van de Oosterschelde is uniek en verschilt van alle andere grote baaien in Europa.

De Gewone zeehond (H1365) verkeert landelijk in een gunstige staat van instandhouding. Voor de Deltawateren geldt een regiodoelstelling van minstens 200 dieren. Deze doelstelling wordt, mede dankzij immigratie vanuit andere gebieden, met ca. 577 dieren in 2013 ruimschoots gehaald (Wijsman $\&$ Goudswaard, 2015). Een tweede doelstelling is dat de populatie in de Delta zelfstandig levensvatbaar is. In Reed et al. (2003) is een overzicht gegeven van de minimale levensvatbare populatieomvang van een groot aantal vertebraten. De Gewone zeehond komt in dit overzicht niet voor, maar wel is de Grijze zeehond opgenomen. Van deze soort is de minimale levensvatbare populatieomvang 2344 individuen. Het is dus niet te verwachten dat het aantal van 577 Gewone zeehonden in 2013 in de Delta levensvatbaar is.

Tenslotte zijn er diverse broedvogels en niet-broedvogels die de slikken en platen gebruiken om te foerageren en als hoogwatervluchtplaats of die duikend hun voedsel verzamelen in diepere delen van de Oosterschelde. 


\section{Effectenanalyse}

In dit hoofdstuk worden de te verwachten effecten van de oesterkweekexperimenten op de volgende natuurwaarden besproken: Grote baaien, Gewone zeehonden, broed- en niet-broedvogels. Voor ieder van deze natuurwaarden is specifiek gekeken naar de potentiële effecten als gevolg van de kweekactiviteiten.

\subsection{Verstoring van beschermde soorten}

Kweekactiviteiten kunnen vogels en zeehonden verstoren. De activiteiten in het kader van dit project vinden echter niet iedere dag plaats, zijn beperkt in omvang en zijn van korte duur (zie 2.2.4). $\mathrm{Er}$ wordt geen geluidsapparatuur, anders dan ten behoeve van communicatiedoeleinden, gebruikt. Anderzijds kunnen kweeksystemen ook positieve effecten op beschermde soorten hebben, omdat ze dienen als kunstmatige rustplaats (Kamermans et al., 2014), beschutting leveren of mogelijk ook voedsel in de vorm van vissen en macroalgen aantrekken. De rustplaats is vooral van belang als de installaties onder water staan. De palen steken dan net boven water. Roofvogels zoeken over het algemeen hoge palen. Daarom wordt een negatief effect van extra predatie door roofvogels niet verwacht. Vogeltellingen zijn gepland in het begeleidende onderzoek (zie bijlage 2). Verstoring van vogels door gebruik van verlichting is bij oesterteelt niet aan de orde.

De kweeklocaties zijn meer dan 1500 m verwijderd van zeehondenrustplaatsen (Kamermans \& Smaal, 2014). Het werpen van jongen vindt plaats op rustig gelegen platen. In de buurt van de proeflocaties zijn geen opgroei- en rustgebieden van de zeehond gesitueerd, aangezien deze gebruik maken van platen met vrij steile randen en die zijn hier niet. Daarom wordt geen effect van de activiteit op zeehonden verwacht.

Visuele verstoring betreft verstoring door de aanwezigheid en/of beweging van mensen dan wel voorwerpen die niet thuishoren in het natuurlijke systeem. Visuele verstoring leidt vooral tot vluchtgedrag van dieren. De soort reageert bijvoorbeeld op beweging omdat een potentiële vijand wordt verwacht. Andersom kan optische verstoring juist ook het uitzicht van soorten beperken waardoor zij potentiële vijanden niet zien naderen. De oesterteelt experimenten worden in het litoraal uitgevoerd waardoor de kweeksystemen met laag water te zien zijn boven water. Het zijn $60 \mathrm{~cm}$ hoge opstellingen die niet bewegen. Uit een lerse studie naar effecten van oesterkweek op in het litoraal geplaatste tafels (Atkins, 2012) blijkt dat meetbare verstoring alleen af en toe werd waargenomen en dat die meetstal klein waren (vogels vlogen op, maar landen weer dichtbij). Deze studie werd uitgevoerd in een vergelijkbaar gebied, maar dan bij veel grootschaliger opstellingen. Daarom wordt bij de hier voorgestelde proef geen effect op vogels verwacht Het monitoren van vogels is onderdeel van het monitoringprogramma (zie onderzoeks- en monitoringplan in bijlage 2). Daar de kweek plaatsvindt op een oesterperceel is geen sprake van extra verstoring door varende schepen.

De werkzaamheden ten behoeve van het kweken van oesters kunnen door het daarbij geproduceerde geluid en de bewegingen leiden tot een tijdelijke verstoring van de in het gebied aanwezige fauna. Dat geldt ook voor het geluid (incl. trillingen) en de beweging van het schip waarmee het systeem wordt geplaatst en onderhouden. Het geluid door de oesterkweek en de bijbehorende scheepvaart bestaat uit geluid boven water en onder water. Geluid boven water kan tot verstoring van vogels leiden. Onderwaterge6luid kan leiden tot verstoring van vissen en zeezoogdieren. De activiteit is locatie gebonden, kleinschalig en beperkt in de tijd. Er wordt gemiddeld 2 maal per maand over een periode van 2-4 uur gewerkt.

Het gaat uitsluitend om verstoring van tijdelijke aard, aangezien de activiteit van korte duur is en de verstoring ophoudt zodra de activiteit is voltooid. Daarom is de verwachting dat er geen sprake is van extra verstoring door de voorgestelde off-bottom kweekexperimenten. In tegendeel, de motor van het schip is uit als er gewerkt wordt aan de off-bottom kweekopstellingen, terwijl bij het gebruik als 
oesterinvangperceel de motor aan is als er gezaaid of gevist wordt. Ook de populatiedynamiek van beschermde soorten wordt niet verstoord.

\subsection{Verontreiniging}

Bij het kweken van oesters en het oogsten ervan komen geen chemische stoffen in het water. De oesterteelt vindt plaats in kunststof zakken en mandjes. De tafels zijn gemaakt van betonijzer en de lijnen voor mandjes zijn gespannen tussen houten palen. Door stormen gepaard met grote golfkracht raken deze materialen of delen daarvan soms los en komen dan in het ecosysteem terecht. Ook bestaat de kans dat door werkzaamheden, als uitdunnen en oogsten of door verwering, kleine partikels (microplastics) in het ecosysteem terecht komen. Daarbij is het mogelijk dat deze deeltjes vervolgens opgenomen worden door filtrerende organismen (b.v. oesters of mosselen) of door sediment etende organismen (b.v. wormen). Recent onderzoek laat zien dat mosselen microplastics uit het water kunnen filtreren (Wegner et al., 2012). De zakken en manden hebben worden doorgaans na 5 jaar vervangen. Er wordt geen afval achter gelaten. De te gebruiken installaties zijn deugdelijk van constructie. Er zijn geen aanwijzingen dat slijtage van de materialen effecten zullen hebben op het ecosysteem. Indien overmatige slijtage van de kunststof wordt geconstateerd, worden deze binnen twee weken vervangen. Op basis van de beschikbare kennis en mitigerende maatregelen worden geen als significante nadelige effecten verwacht op de instandhoudingsdoelen.

De geplande experimenten gaan gepaard met scheepsbewegingen van en naar het gebied met percelen. Op het perceel zal het schip stil liggen om de werkzaamheden aan de zakken en manden te kunnen uitvoeren. Dit in tegenstelling tot oesterinvang waarbij het schip vaart om schelpen te zaaien en te oogsten. Het monitoren van scheepsbewegingen is onderdeel van het monitoringprogramma (zie onderzoeks- en monitoringplan in bijlage 1). De Aerius calculator (https://calculator.aerius.nl/calculator/) berekent de stikstofuitstoot voor verschillende menselijk activiteiten. Een Aerius berekening is uitgevoerd voor de categorie koelschepen en vissersschepen en deze geeft aan "There are no nature areas with calculation result higher than the threshold". Extra stikstofdepositie is dus niet aan de orde.

\subsection{Verandering dynamiek substraat}

Het aangewezen habitattype in de Oosterschelde is H1160 Grote baaien. Typische soorten van dit habitat type kunnen beïnvloed worden door de voorgenomen activiteit. Schelpdieren filtreren organische en anorganische deeltjes uit het water. Slechts een deel van het gefilterde materiaal wordt verteerd in het maag-darm kanaal waarbij de restproducten worden uitgescheiden als faeces. De rest gaat niet door het maag-darmkanaal, en wordt daarvoor reeds verwijderd als pseudofaeces. Pseudofaeces en faeces bezitten hoge gehaltes aan organische stof. Ze bezinken richting bodem (depositie) en worden tijdens dit proces door de waterstroming meegevoerd en verspreid, vaak ook weer opgewerveld en verder gevoerd tot ze opnieuw bezinken (de Mesel et al., 2008). Het organisch rijker worden van de bodem als gevolg van depositie kan leiden tot verandering van de omstandigheden voor soorten die in arme omstandigheden voorkomen. Andere soorten kunnen juist baat hebben bij depositie en verrijkte omstandigheden. Bepalende factoren daarbij zijn de mate waarin golven en stroming organisch materiaal verspreiden en de kwetsbaarheid van het natuurlijk bodemleven.

De experimenten met de teelt van oesters zijn gepland op oesterbroedinvangpercelen. Er heeft nog niet eerder oesterteelt op deze percelen plaatsgevonden. De verwachting is dat er geen significante effecten van veranderingen in stroming rond de tafels met zakken en lijnen met mandjes zal optreden. Daarom wordt voor de percelen geen verandering in dynamiek van het substraat als gevolg van bezinken van pseudofaeces en faeces verwacht. Het slibgehalte in de bodem is onderdeel van het monitoringprogramma (zie onderzoeks- en monitoringplan in bijlage 1). 


\subsection{Verandering soortensamenstelling}

De tafels met zakken en lijnen met manden worden in het litoraal van Kom van de Oosterschelde geplaatst op oesterpercelen. De bestemming van deze percelen is oesterteelt. Daarom wordt geen effect op de kwaliteit van het bodemhabitat verwacht.

\subsection{Verstoring of verlies oppervlakte}

Oesterkweek in zakken en mandjes kan effect hebben op de kwaliteit van het habitattype H1160 door beïnvloeding van natuurlijke processen (stromingspatronen, sedimentatie en erosie). Doordat er voor de lijnen palen in de bodem worden aangebracht en onder de poten van de tafels geen bodemleven kan plaatsvinden is er feitelijk sprake van verlies van een habitatoppervlakte van enkele vierkante meters. Ten opzichte van het oppervlakte van de Oosterschelde is dit met zekerheid niet relevant. Indien de palen en tafels worden verwijderd, zal ter plaatse met zekerheid herstel van de bodem en het bodemleven optreden. Het effect is derhalve niet onomkeerbaar. De tafels kunnen door schaduwwerking de lichtinval op de bodem beperken, waarmee het plantaardige bodemleven ter plaatse nadelig kan worden beïnvloed. Hier is nog erg weinig over bekend; bepaling van de concentratie aan bodemdiatomeeën is onderdeel van het monitoringprogramma (zie onderzoeks- en monitoringplan in bijlage 2). Bodemdiatomeeën zijn de planten die onder de tafels voorkomen op perceel YE 74 en 75.

De ligging van de zoutgradiënt, uitgedrukt als de verhouding zout en brak gebied binnen habitattype 1160, wijzigt niet. De water(bodem)kwaliteit, uitgedrukt als de concentraties nutriënten en milieuvreemde stoffen, wijzigt eveneens niet.

De voorgenomen activiteit heeft geen significant effect op het ontstaan van meerjarige stabiele mosselbanken, aangezien er niet op de bodem wordt gevist. Ook voor het uitgangsmateriaal worden alleen oestertjes gebruikt die niet afkomstig zijn uit gebieden met meerjarige stabiele mosselbanken of oude oesterbanken.

Oesters filtreren organische en anorganische deeltjes uit het water. Deze filtratiedruk kan de draagkracht van de voedselketen beïnvloeden (zie Kamermans et al., 2014; Smaal et al., 2013). Op de percelen waar de zakken staan of mandjes hangen, kunnen geen oesters op de bodem worden gekweekt. Het effect op de draagkracht zal daarom niet veranderen. Extra redenen waarom er geen effecten op de draagkracht en op de instandhoudingsdoelen te verwachten zijn:

- Het totale areaal aan oesterbanken op droogvallende platen in de Oosterschelde is in het voorjaar van 2014 door I MARES geschat op 652 hectare. Daarmee lijkt het areaal met 127 hectare (16\%) afgenomen ten opzichte van 2013 (van den Ende et al., 2014, zie ook van den Ende et al.,2016). Een deel van deze afname (ca. $43 \mathrm{ha}$ ) wordt verklaard uit het feit dat de sublitorale oesters (op percelen en op de bank bij Kattendijke) buiten beschouwing zijn gelaten. De rest van de afname kan verklaard worden doordat het areaal aan oesterbanken in de kom van de Oosterschelde is afgenomen. Ten opzichte van 2013 ligt er 89 hectare minder aan oesterbanken. Deze afname wordt waarschijnlijk veroorzaakt door het wegvissen van Japanse oesters in dit gebied. In de rest van de Oosterschelde lijkt het areaal aan oesterbanken stabiel (van den Ende et al., 2014, 2016).

- De hoeveelheid oesters is afhankelijk van het succes van de broedval en de mortaliteit. Er is de laatste jaren overal in de Oosterschelde sterfte onder éénjarige oesters als gevolg van het oester herpes virus, waardoor het bestand aan oesters op de kweekpercelen laag is. Er is geen sprake van een volledige bezetting van de kweekpercelen. De draagkrachtberekeningen voor de Oosterschelde gaan uit van een worst-case scenario, waarbij ervan uitgegaan wordt dat de percelen volledig benut worden. Dit is al jaren niet het geval. Het project is tijdelijk en de verwachting is dat bovenstaande situatie niet in een paar jaar zal veranderen.

- In het project gaat het om een kleine hoeveelheid oesters op oesterpercelen en op een plaats waar in de directe omgeving oesters voorkomen; op het totaal van $10 \mathrm{mln} \mathrm{kg}$ bedraagt de experimentele stock van $79.000 \mathrm{~kg}$, overeenkomende met $0,79 \%$.

- De verwachting is dat off-bottom oesters iets sneller groeien, daarnaast bevatten de installaties meer oesters dan op hetzelfde oppervlak op de bodem gekweekt zouden worden. Dit vergoot de 
efficiëntie van de oesterkweek. Dat is een van de doelstellingen van het Plan van Aanpak 'Oestermaatregelen' 2016 - 2018 (NOV, 2016).

- Een eventueel effect op draagkracht door gebruik van hatchery oesters zal worden gemitigeerd door het wegvissen van wilde oesters die aanwezig zijn op de percelen waar ook de kweek plaatsvindt. Hierbij kan zoveel biomassa worden weggevist als maximaal aanwezig zal zijn bij oogst.

Op grond van het bovenstaande komen wij tot de conclusie dat er geen effect is op de draagkracht. In navolging van de meerjarige productie- en effectmetingen aan mosselzaadinvanginstallaties (MZI's) (project 2009-2013; Kamermans et al. 2013), loopt er momenteel een programma ('Draagkracht MZI') in opdracht van het ministerie van EZ (Kamermans \& van Asch, 2016). De centrale vraag bij dit onderzoek is: Heeft de opschaling van MZI's effect op de draagkracht voor schelpdieren in de Waddenzee en Oosterschelde? Monitoring is van belang om mogelijke effecten van de opschaling zichtbaar te maken en te kunnen evalueren. De indicatoren voor een veranderende draagkracht die worden onderzocht, zijn het vleesgehalte van aangevoerde mosselen en de groei van kokkels zoals die blijkt uit de jaarlijkse surveys. Het gebruik van de draagkrachtindicatoren werkt als volgt: een afname van het vleesgehalte van mosselen en een afname van de groei van kokkels wijzen op een afname van de draagkracht voor schelpdieren. Uit Smaal et al. (2013) blijkt dat vleesgehalte een goede indicatie van draagkracht is. Met dit onderzoek is het mogelijk een vinger aan de pols te houden. Analyse van de data tot en met 2014 laat zien dat het vleesgehalte van mosselen en de groei van kokkels in de Oosterschelde fluctueert in ruimte en tijd, maar geen trend in de tijd vertoont (Kamermans \& van Asch, 2016).

Effecten op de kwaliteit van habitattype 1160 (grote ondiepe kreken en baaien) zijn niet te verwachten, omdat door de voorgenomen activiteit het oppervlak of de kwaliteit van het habitattype niet wordt aangetast. Tevens is geen negatief effect op vissen is te verwachten, daar de kweek geheel in zakken of mandjes plaatsvindt.

\subsection{Vogels}

De oesters worden gekweekt in zakken en mandjes op oesterpercelen in het litoraal van Kom van de Oosterschelde. In de omgeving van de installaties wordt door diverse vogelsoorten gefoerageerd in het water en op de droogvallende platen. Voor de meeste vogelsoorten geldt een behoudsdoelstelling voor omvang kwaliteit (Tabel 1). Alleen voor de Strandplevier geldt een uitbereidingsdoelstelling areaal of verbeterdoelstelling kwaliteit (Tabel 1 ).

Omdat rond laagwater op de platen wordt gewerkt en de afstand tot de laagwaterlijn dan meer dan $400 \mathrm{~m}$ bedraagt, zullen vogels die in het water foerageren zich buiten de vluchtafstand bevinden (Tabel 2). Voor de vogels die op het open water verblijven, zal de verstoring derhalve niet aan de orde zijn, als zij zich buiten de verstoringsafstand bevinden wanneer de werkzaamheden plaatsvinden. Dit geldt niet voor de drie ganzen soorten die zijn geobserveerd in het studiegebied. De Brandgans is niet meer aangetroffen sinds 2012, de Grauwe gans wordt sinds 2012 in zeer lage aantallen geobserveerd (1-2 individuen), en de Rotgans is in 2014 aanwezig in lage aantallen (8 individuen). Door gewenning van ganzen aan de menselijke aanwezigheid en vaarbewegingen voor de experimentele oesterteelt wordt op die afstand geen noemenswaardige verstoring van ganzen verwacht.

Tabel 2. Verstoringsgevoeligheid van vogels die in het water foerageren in het studiegebied OS640. De aangegeven afstanden zijn gebaseerd op Krijgsveld et al. (2008).

\begin{tabular}{|c|c|c|c|}
\hline soort & $\begin{array}{c}\text { Aanwezig in } \\
\text { studiegebied }\end{array}$ & vluchtafstand $(\mathrm{m})$ & alert afstand $(\mathrm{m})$ \\
\hline A004 Dodaars & $\mathrm{X}$ & 200 & 400 \\
\hline A005 Fuut & $\mathrm{X}$ & 200 & 400 \\
\hline A017 Aalscholver & $\mathrm{X}$ & 75 & 150 \\
\hline A069 Middelste Zaagbek & $\mathrm{X}$ & 250 & 575 \\
\hline A037 Kleine zwaan & & 175 & 400 \\
\hline A043 Grauwe gans & $\mathrm{X}$ & 566 & 3125 \\
\hline A045 Brandgans & $\mathrm{X}$ & 566 & 3125 \\
\hline
\end{tabular}




\begin{tabular}{|c|c|c|c|}
\hline A046 Rotgans & $X$ & 566 & 3125 \\
\hline A125 Meerkoet & $X$ & 100 & 200 \\
\hline
\end{tabular}

Voor de broedgebieden geldt een verstoringafstand van $500 \mathrm{~m}$ (J ongbloed et al., 2009).

Broedgebieden van de soorten broedvogels uit Tabel 1 (Kluut, Bontbekplevier, Strandplevier) komen niet voor binnen $500 \mathrm{~m}$ van de werkingssfeer van de oesterkweeksystemen op perceel Yerseke Bank 74 en 75 (http://www.synbiosys. alterra.nl/natura2000/gebiedendatabase. aspx?subj=profielen ). Daarom worden geen effecten verwacht op geen van de beschermde broedvogelsoorten.

Verstoring van vogels op hoogwatervluchtplaatsen wordt niet verwacht, omdat de werkzaamheden plaats vinden tijdens laagwater. De soorten die binnen de werkingssfeer van het oesterkweeksysteem op de droogvallende platen foerageren zijn, met hun verstoringsafstanden, weergegeven in Tabel 3.

Het ontwerp-beheerplan Oosterschelde signaleert een knelpunt voor bereikbaarheid van geschikte foerageergebieden voor steltlopers: door de zandhonger in de Oosterschelde zal het foerageergebied gaan krimpen. Dit geldt met name voor Bontbekplevier, Bonte strandloper, Drieteenstrandloper, Groenpootruiter, Kanoet, Kluut, Rosse grutto, Scholekster, Steenloper, Strandplevier, Tureluur, Wulp, Zilverplevier. Rijkswaterstaat data van tellingen uit 2005 t/m 2014 op de locatie die zich het dichts bij percelen 74/75 bevindt, zijn toegevoegd in bijlage 3. Hieruit blijkt dat de Drieteenstrandloper en Strandplevier niet voorkomen in de nabijheid van perceel 74/75. De locatie laat zeer lage aantallen zien (bijlage 3) ten opzichte van de doelstelling (tabel 1) voor de Bontbekplevier, Bonte strandloper, Groenpootruiter, Kanoet, Kluut (1x 1 exemplaar waargenomen in januari 2013), Rosse grutto en de Zilverplevier. Van de Scholeksterpopulatie bevindt 10\% van de doelstelling zich $2005 \mathrm{t} / \mathrm{m} 2014$ op de locatie nabij perceel $74 / 75$. Voor de Tureluur is dat $25 \%$, de Wulp $30 \%$ en de Steenloper is in aantallen hoger dan de doelstelling geobserveerd.

Vooral voor Scholekster, Tureluur en Wulp zijn effecten van verstoring dus van belang. De eerder genoemde lerse studie (Atkins 2012) liet zien dat de soorten die een neutrale of positieve reactie hadden op oesterkweek op tafels soorten zijn die in kleine groepen foerageren zoals de Scholekster, Tureluur en Wulp. De studie in Ierland is representatief voor de teelt van oesters op tafels in het litoraal van een estuarium waar dezelfde soorten vogels voorkomen als in de Kom van de Oosterschelde. De schaal van de opstellingen is echter groter in Ierland dan de geplande schaal van de huidige aanvraag.

Tabel 3. Verstoringsgevoeligheid van vogels die op de platen foerageren in het studiegebied OS640. De aangegeven afstanden zijn gebaseerd op Krijgsveld et al. (2008).

\begin{tabular}{|c|c|c|c|}
\hline soort & $\begin{array}{c}\text { Aanwezig in } \\
\text { studiegebied }\end{array}$ & vluchtafstand $(\mathrm{m})$ & alert afstand (m) \\
\hline A026 Kleine zilverreiger & & 75 & 125 \\
\hline A034 Lepelaar & & 75 & 125 \\
\hline A037 Kleine zwaan & & 566 & 400 \\
\hline A043 Grauwe gans & & 566 & 3125 \\
\hline A045 Brandgans & & 566 & 3125 \\
\hline A046 Rotgans & & 100 & 175 \\
\hline A103 Slechtvalk & & 100 & 175 \\
\hline A130 Scholekster & $\mathrm{X}$ & 100 & 175 \\
\hline A132 Kluut & $\mathrm{x}$ & 100 & 175 \\
\hline A137 Bontbekplevier & $\mathrm{x}$ & 100 & 175 \\
\hline A138 Strandplevier & & 100 & 175 \\
\hline A140 Goudplevier & $\mathrm{x}$ & 100 & 175 \\
\hline A141 Zilverplevier & $\mathrm{x}$ & 125 & 300 \\
\hline A143 Kanoetstrandloper & $\mathrm{x}$ & 125 & 300 \\
\hline A144 Drieteenstrandloper & $\mathrm{x}$ & 125 & 300 \\
\hline A149 Bonte strandloper & & 125 & 300 \\
\hline A157 Rosse grutto & & & \\
\hline
\end{tabular}




\begin{tabular}{|c|c|c|c|}
\hline A160 Wulp & $\mathrm{X}$ & 125 & 300 \\
\hline A161 Zwarte ruiter & & 125 & 300 \\
\hline A162 Tureluur & & 125 & 300 \\
\hline A164 Groenpootruiter & $\mathrm{X}$ & 125 & 300 \\
\hline A169 Steenloper & $\mathrm{X}$ & 125 & 300 \\
\hline
\end{tabular}

$\mathrm{x}$ : aanwezig maar in relatief laag aantal

$\mathrm{X}$ : aanwezig in relatief groot aantal

De vormgeving van de zakken en manden is zodanig dat vogelsoorten er niet in verstrikt kunnen raken. Tijdens elk bezoek worden de systemen gecontroleerd op vogelslachtoffers.

Er zijn geen als significant te beoordelen effecten op vogels en de omvang van hun leefgebied te verwachten; het monitoren van vogels is onderdeel van het monitoringprogramma (zie onderzoeksen monitoringplan in bijlage 1).

\subsection{Habitatsoorten}

De Oosterschelde is voor een tweetal habitatsoorten aangewezen: de Gewone zeehond (H1365) en de Noordse woelmuis (H1340). De Noordse woelmuis komt niet voor in het gebied waar de projecten plaatsvinden (Fig. 7).

De Oosterschelde heeft voor zeehonden een functie als voedsel- en verblijfgebied. Voor het vervullen van deze functies zijn platen met aanliggende diepe geulen van belang. Het werpen van jongen vindt plaats op rustig gelegen platen. Zeehondenligplaatsen bevinden zich in het midden en het westen van de Oosterschelde. In de buurt van de kweeklocatie zijn geen opgroei- en rustgebieden van de zeehond gesitueerd, waardoor geen significante effecten op de populatie Gewone zeehonden te verwachten zijn (Wijsman \& Goudswaard, 2015). 


\section{$6 \quad$ Mitigerende maatregelen}

De te gebruiken installaties zijn deugdelijk van constructie. Indien overmatige slijtage van de kunststof wordt geconstateerd worden deze binnen een maand vervangen. Er wordt geen geluidsapparatuur anders dan ten behoeve van communicatiedoeleinden gebruikt. Er wordt geen afval achter gelaten. De werkzaamheden worden bij daglicht uitgevoerd. Tijdens elk bezoek worden de systemen gecontroleerd op vogelslachtoffers. Een eventueel effect op draagkracht door gebruik van hatchery oesters zal worden gemitigeerd door het wegvissen van wilde oesters die aanwezig zijn op de percelen waar ook de kweek plaatsvindt. Hierbij kan zoveel biomassa worden weggevist als maximaal aanwezig zal zijn bij oogst. Door de teelt in zakken en mandjes wordt predatie door oesterboorders voorkomen. 


\section{$7 \quad$ Cumulatieve effecten}

De productie van oesters uit de hatchery vergroot het bestand aan schelpdieren in de Oosterschelde. Dit kan via een extra beslag op het aanwezige voedsel (microalgen) een effect hebben op de instandhoudingsdoelen voor de beschermde natuurwaarden en kenmerken. Boven een bepaalde graasdruk door schelpdieren kan de beschikbaarheid van microalgen minder worden. Dit kan doorwerken in een verminderde groei van de schelpdieren die op hun beurt weer als voedsel dienen voor bepaalde vogelsoorten. Het effect wordt bepaald door de mate van waterverversing, het niveau van de algenproductie en de filtratiedruk vanuit de natuur en schelpdierkweek. Er is geen vaste draagkrachtdrempel aan te wijzen, omdat de beschikbaarheid van algen van vele factoren tegelijkertijd afhankelijk is (de watertemperatuur, de hoeveelheid licht in het water, de hoeveelheid voedingsstoffen voor de algen, de aanwezigheid van andere soorten die algen eten (schelpdieren, zoöplankton, etc.). Wel kan worden aangegeven in hoeverre de voorgenomen activiteit een substantiële bijdrage kan leveren in het vergroten van de hoeveelheid schelpdieren die algen eten, of in hoeverre de vergroting wegvalt in de ruis rondom de voedselbeschikbaarheid die wordt veroorzaakt door de andere bovengenoemde factoren. Een effect op de draagkracht (voedselbeschikbaarheid) kan een doorwerking hebben op de beschermde soorten wanneer hierdoor de groei van natuurlijke schelpdierbestanden wordt beïnvloed (schelpdieretende vogels) ofwel de beschikbaarheid van microalgen via schakels als zoöplankton effecten heeft via de voedselketen (overige soorten). Voor de N2000-doelen gaat het met name om schelpdieretende vogels. Deze foerageren op droogvallende platen en eten voornamelijk kokkels. De toename van het bestand zal ca 0,79 \% bedragen ten opzichte van het totaal. Uit voorzorg kan een eventueel effect op draagkracht worden gemitigeerd door het wegvissen van wilde oesters die aanwezig zijn op de percelen waar ook de kweek plaatsvindt. Hierbij kan zoveel biomassa worden weggevist als maximaal aanwezig zal zijn bij oogst. Omdat de experimenten geheel op oesterinvangpercelen plaatsvinden, wordt ook het areaal niet significant vergroot. Als er tafels op het perceel worden geplaatst is het perceel niet in gebruik als broedvangperceel. Er worden geen schelpen uitgezaaid en geen broed ingevangen. Er is dus geen sprake van dubbele bezetting. In opdracht van het ministerie van Economische Zaken wordt in het kader van het mosselconvenant de draagkracht van de Oosterschelde voor schelpdieren gemonitord (Kamermans \& van Asch, 2016). Met dit onderzoek is het mogelijk een vinger aan de pols te houden. De methode is operationeel (project gefinancierd door EZ) en gebaseerd op studies die zijn uitgevoerd gedurende het project Meerjarige effect- en productiemetingen aan MZI's in de Westelijke Waddenzee, Oosterschelde en Voordelta (ook gefinancierd door EZ, Kamermans et al, 2014).

Er wordt geen effect verwacht op het leefgebied van op het water levende vogels door de geplande experimenten en vaarbewegingen. Een cumulatief effect door de aanwezigheid van mosselzaadinvanginstallaties (MZI's) en mosselhangcultures (MHCs) in de Oosterschelde wordt dan ook niet verwacht. De geplande experimenten gaan gepaard met scheepsbewegingen van en naar de proeflocatie. De proeflocatie bevindt zich in de Kom van de Oosterschelde. Dit is een gebied waar dagelijks vaarbewegingen plaats vinden in verband met werk op de percelen.

De zandhonger van de Oosterschelde wordt niet vergroot door de oesterkweekinstallaties. Verandering in slibgehalte zal niet significant zijn. 


\section{$8 \quad$ Conclusie}

Experimentele oesterkweek op percelen Yerseke bank 74 en 75 in het litoraal van Kom van de Oosterschelde is geanalyseerd wat betreft de effecten op de Natura 2000-

instandhoudingsdoelstellingen van habitats en soorten. Ook is ingegaan op mitigerende maatregelen en cumulatieve effecten.

De conclusie is dat er op basis van de beschikbare informatie die in voorliggende Passende Beoordeling is samengevat geen significante negatieve effecten worden verwacht van experimentele oesterkweek op percelen Yerseke bank 74 en 75 in het litoraal van Kom van de Oosterschelde op de Natura 2000-instandhoudingdoelstellingen van habitats en soorten en aan de orde zijnde verbeteropgaven voor deze gebieden. 


\section{Kwaliteitsborging}

I MARES beschikt over een ISO 9001:2008 gecertificeerd kwaliteitsmanagementsysteem (certificaatnummer: 187378-2015-AQ-NLD-RvA). Dit certificaat is geldig tot 15 september 2018. De organisatie is gecertificeerd sinds 27 februari 2001. De certificering is uitgevoerd door DNV Certification B.V. 


\section{Literatuur}

Atkins (2012) The effects of intertidal oyster culture on the spatial distribution of waterbirds. Marine Institute Report.

Boudry, P. (2008). Review on Breeding and Reproduction of European aquaculture species Pacific oyster (Crassostrea gigas). Aqua Breeding report.

Dundon, W.G., I. Arzul, E. Omnes, M. Robert, C. Magnabosco, M. Zambon \& G. Arcangeli (2011). 'Detection of Type 1 Ostreid Herpes variant (OsHV-1 $\mu$ var) with no associated mortality in Frenchorigin Pacific cupped oyster Crassostrea gigas farmed in Italy'. In: Aquaculture, 314(1), 49-52.

Faasse, M. A. \& M. Ligthart (2009). American (Urosalpinx cinerea) and Japanese oyster drill (Ocinebrellus inornatus) (Gastropoda: Muricidae) flourish near shellfish culture plots in The Netherlands. Aquatic Invasions 4: 321-326.

Gagnaire B., P. Soletchnik, P. Madec, P. Geairon, O. Le Moine \& T. Renault (2006). Diploid and triploid Pacific oysters, Crassostrea gigas (Thunberg), reared at two heights above sediment in MarennesOleron Basin, France: Difference in mortality, sexual maturation and hemocyte parameters. Aquaculture 254: 606-616.

Garnier-Gere, P.H., Naciri-Graven, Y., Bougrier, S., Magoulas, A., Heral, M., Kotoulas, G., Hawkins, A., Gerard, A. (2002). Influences of triploidy, parentage and genetic diversity on growth of the Pacific oyster Crassostrea gigas reared in contrasting natural environments. Mol. Ecol. 11, 1499- 1514.

Guo, X., Debrosse, G.A. \& Allen, S.K.J r. (1996). All triploid oysters (Crassostrea gigas Thunberg) produced by mating tetraploids and diploids, Aquaculture, 142: 149-161.

Janssen, J.A.M. \& J.H.J. Schaminée (2009). Europese natuur in Nederland. Natura 2000-gebieden van Zee en Kust. Zeist, KNNV Uitgeverij.

Jongbloed, R.H., A.C. Smaal, C.J. Smit, M. Poelman, A.G. Brinkman, N.M.J.A. Dankers, I.G. de Mesel \& J.A. van Franeker (2009). Ecologische analyse van potentiële locaties voor mosselzaadinvang (MZI) in Nederlandse kustwateren I MARES Rapport C088/09.

Kamermans, P., M. Poelman \& M.Y. Engelsma (2013). Oesterherpesvirus: een overzicht. I MARES, Rapportnummer: Factsheet, 2 pagina's.

Kamermans, P., C. Smit, J. Wijsman \& A. Smaal (2014). Meerjarige effect- en productiemetingen aan MZI's in de Westelijke Waddenzee, Oosterschelde en Voordelta: samenvattend eindrapport. I MARES Rapport C191/13.

Kamermans P. \& Smaal A. (2014). Passende Beoordeling (PB) mosselzaadinvang (MZI) op vrije gronden in de Nederlandse kustwateren voor de periode 2015-2018. IMARES Rapport C168/14.

Kamermans P. (2015). Triploïde J apanse oesters: een overzicht. I MARES Factsheet, 2 pagina's

Kamermans P. \& M. van Asch (2016). Monitoring draagkracht voor schelpdieren in relatie tot opschaling MZIs in de Waddenzee en Oosterschelde tot en met 2014. I MARES Rapport C046/16.

Kamermans P. \& A. Smaal (2016). Passende beoordeling ten behoeve van experimentele oesterkweek in het sublitoraal van de Kom van de Oosterschelde. IMARES rapport C013/16.

Krijgsveld K.L., R.R. Smits \& J. van der Winden (2008) Verstoringsgevoeligheid van vogels. Update literatuurstudie naar de reacties van vogels op recreatie. Bureau Waardenburg/Vogelbescherming Nederland rapport nr. 08-173.

Lapègue S., P. Boudry \& P. Goulletquer (2008). Pacific cupped oyster - Crassostrea gigas. Genimpact final scientific report.

Mesel I. De, Meesters H.W.G., Meijboom A. \& Wijsman J.W.M. (2008). Impact van MZI's op organische koolstof in de bodem. I MARES Rapport C037/08.

Ministerie van LNV (2004). Ruimte voor een zilte oogst. Naar een omslag in de Nederlandse schelpdiercultuur. Beleidsbesluit Schelpdiervisserij 2005 - 2020. Ministerie van Landbouw, Natuur en Voedselkwaliteit, Rapport, 46 pagina's.

Ministerie van LNV (2009). Definitief aanwijzingsbesluit Natura 2000-gebied Oosterschelde. Ministerie van Economische Zaken, Landbouw en Innovatie, Rapport.

Ministerie I enM (2015). Natura 2000 Deltawateren Ontwerpbeheerplan Deltawateren 2015-2021 Oosterschelde, Ministerie van Infrastructuur en Milieu | Rijkswaterstaat. Rapport, 95 pagina's. 
Nell J.A. \& Perkins B. (2005). Studies on triploid oysters in Australia: farming potential of all-triploid Pacific oysters Crassostrea gigas (Thunberg), in Port Stephens, New South Wales, Australia. Aquac Res 36:530-536.

NOV (2016) Plan van Aanpak 'Oester-maatregelen' 2016 - 2018.

Reed, D.H.J., J. O'Grady, B.W. Brook, J.D. Ballou \& R. Frankham (2003). Estimates of minimum viable population sizes for vertebrates and factors influencing those estimates. Biological Conservation 113: 23-34.

Robert, R.J.L. Sanchez, L. Perez-Paralle, E. Ponis, P. Kamermans, M. \& O'Mahoney (2012). A glimpse of the mollusc industry in Europe. Aquaculture Europe 38: 5-11.

Smaal A.C., P. Kamermans \& W.J. Strietman (2016). Kennis en onderzoeksagenda voor de Nederlandse oestersector. IMARES Rapport C057/16.

Smaal A.C., T. Schellekens, M.R. van Stralen \& J.C. Kromkamp (2013). Decrease of the carrying capacity of the Oosterschelde estuary (SW Delta, NL) for bivalve filter feeders due to overgrazing? Aquaculture 404-405: 28-34.

Stanley, J.G., H. Hidu \& S.K. Allen Jr. (1984). Growth of American oysters increased by polyploidy induced by blocking meiosis I but not meiosis II. Aquaculture 37: 147-155.

Strietman, W.J., A. Smaal \& B. Bolman (2016). Economische situatie van de oestersector. Potentiele impact van herpesvirus in oesters en Japanse oesterboorder op de oestersector. Quickscan, LEI .

Troost, K. \& H. Van Hulzen (2009). Doelendocument Natura 2000 Deltagebied. Uitwerking van Natura 2000 waarden in omvang, ruimte en tijd, Rapport, 233 pagina's.

Van Bentum, D. \& E. Koolmees (2014). Natura 2000-ontwerpbeheerplan Deltawateren 2015-2021 Oosterschelde (5e concept). Royal Haskoning DHV, Rapport, 69 pagina's.

Van den Ende D., M. van Asch, E.B. Brummelhuis \& K. Troost (2014). Japanse oesterbanken op droogvallende platen in de Nederlandse kustwateren in 2014: bestand en arealen. IMARES Rapport: C172/14.

Van den Ende, D., E. Brummelhuis, C. Van Zweeden, M. Van Asch \& K. Troost (2016). Mosselbanken en oesterbanken op droogvallende platen in de Nederlandse kustwateren in 2015: bestand en arealen, Rapport nummer: IMARES rapport C168/15, 45 pagina's).

Van Maldegem, D. (2004). Ontwikkeling morfologie Oosterschelde in relatie tot zandhongerproblematiek; RIKZ/AB/2004.809x; juli 2004.

Van Stralen, M.R., K. Troost \& A. Gitttenbrerger (2015). Vindplaatsen oesterboorders, najaar 2015. Memo PO Mosselcultuur.

Wegner A., E. Besseling, E.M. Foekema, P. Kamermans \& A.A. Koelmans (2012). Effects of Nanopolystyrene on the Feeding Behaviour of the Blue Mussel (Mytilus edulis L.). Environmental Toxicology and Chemistry 31: 2490-2497.

Wijsman, J.W.M. \& P.C. Goudswaard (2015). Passende Beoordeling vaste vistuigvisserij in de Oosterschelde. Wageningen IMARES, Rapport nummer: C127/15, 69 pagina's. 


\section{Verantwoording}

Rapport C124/16

Projectnummer: 4313200001-07-2

Dit rapport is met grote zorgvuldigheid tot stand gekomen. De wetenschappelijke kwaliteit is intern getoetst door een collega-onderzoeker en het verantwoordelijk lid van het managementteam van I MARES.

Akkoord:

R.H. Jongbloed

Onderzoeker

Handtekening:

Datum:

13-12-2016

Akkoord:

Drs. J. Asjes

Integratie manage

Handtekening:

Datum:

13-12-2016 


\section{Bijlage 1 Factsheet triploïde oesters}

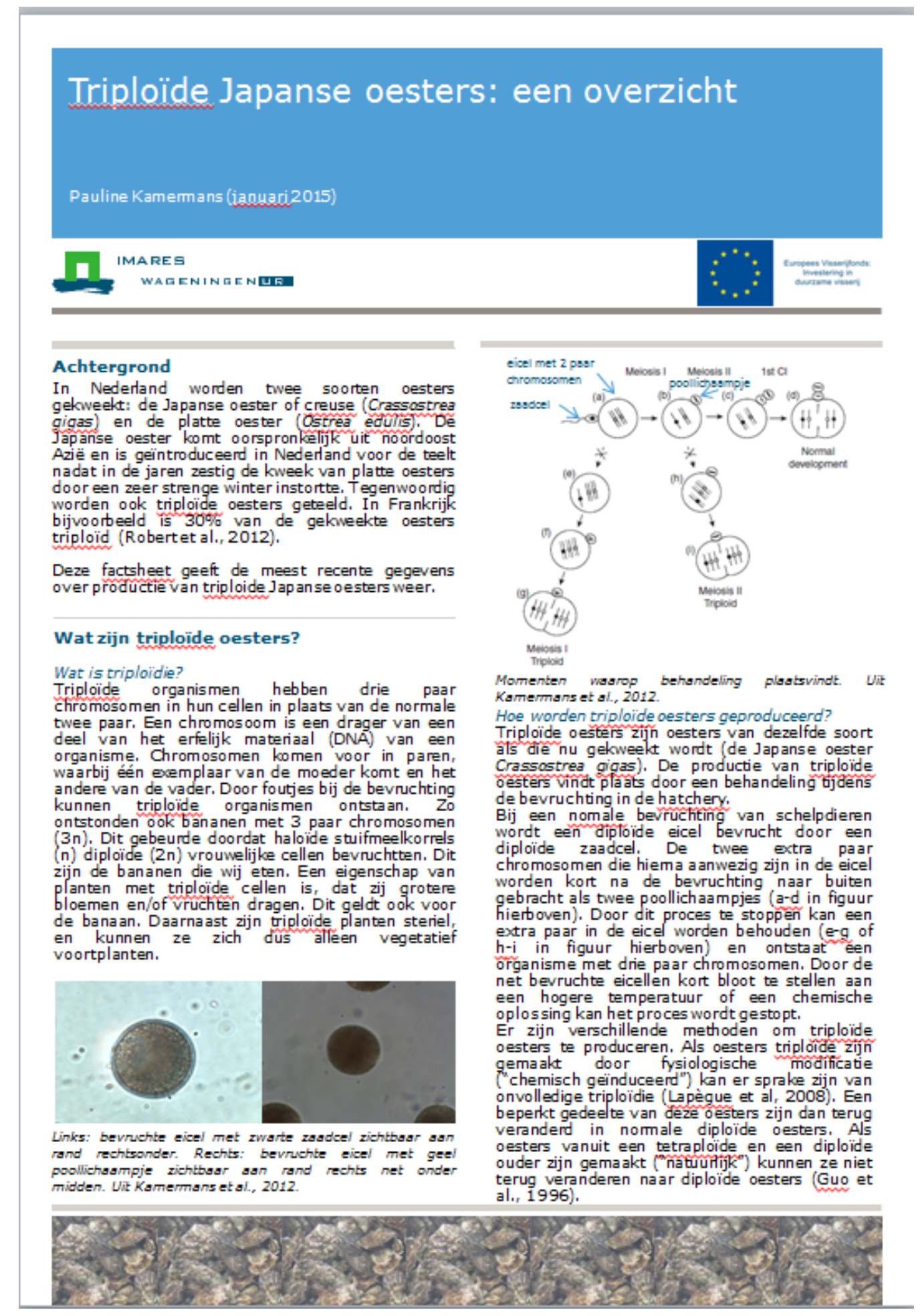




\section{Innovaties}

Waarom worden triploide oesters geproduceerd? Door het extra paar chromosomen zijn triploïde oesters steriel. Omdat geen energie wordt gebruikt voor het ontwikkelen van geslachtsorganen en voor het ontwikelen van geslachiorganen en producten kunnen triploide oesters sneler groeien (Stanley, et al, 1984; Nel \&. Perkins, 2005). pariode dat andere oesters paaien gewicht verliezen (Nell \&. Perkins, 2005; Boudry, 2008). Dit zorgt ervoor dat triploide oesters ook in de zomer verkocht kunnen worden. Ook zijn trioloïde oesters beter resistent tegen stressvolle condities (GamierGere et al., 2002) en vertonen ze een lagere sterfte (Gagnaireet al., 2006).
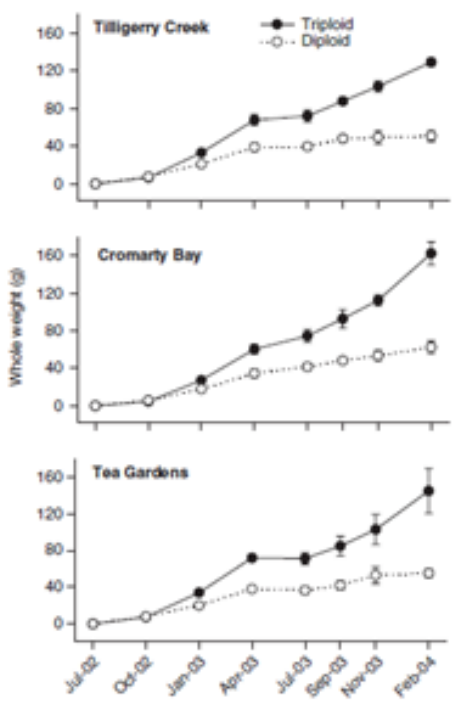

Groei van Japanse briploide en diploide oesters in Port Stevens, Australie. Uit Neil \& Perkins, 2005.

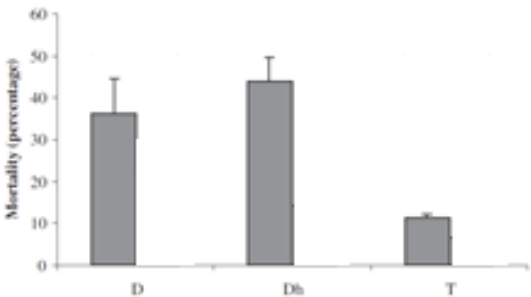

Sterfte percentage van in het wild opgevangen oesters (D). hatehery geproduceerde oesters (Dh) en briploids oesters (T) gekweekt van mast tot september 2002 in zakken op tafels in Marennes-Qleron, Frankrijk. U/L Gagnaire et at., 2006.

\section{Onderzoek}

In 2014 is het project Ontwikkeling triploide oester voor Yerseke gestart. Het project wordt gefinancierd in het kader van de subsidieregeling Operationeel Programma "Perspectief voor een duurzame Visserij" In dit project werkt de Roem van Yerseke BV samen met Bonton Products BV, Prins \&. Dingemanse BV en IMARES. De hatchery van de Roem van Yerseke za triploide en diploid oesterbroed produceren. IMARES begeleidt de proef. De groei, overleving en kwaliteit van triploïde en diploïde oesters wordt vervolgens vergeleken in mandjes en zakken in de Oosterschelde. Roem van Yerseke, BV, Bonton Products BV en Prins \&. Dingemanse BV zullen de oesters in het veld monitoren.

\section{Referenties}

Boudry, P. (2008) Review on Bresding and Reproduction of Europesn aquaculture species Pacific oyster (Craseostres gigas). Aqus Breeding report.

Gagnaire B, P Soletehnik, PM adec, P Geaino, OL- Moine, T Renault (2006) Diploidand triploid Pacificoysters, Crassostrea gigss (Thunberg), reared at two heights Qbovesediment in Marennes-Oleron Basin, Frana: Difference in mortality, sexual maturation and hemocyte parameters. Aquaculture 254: 606-616.

Garnier-Gere, P.A., Naciri-Graven, Y., Bougrier, S., Magoulas, A., Heral, M., Rotoulas, G., Hawkirs, A., Gerard, A. 2002. Influencess of triploidy, parentage and genetic diversity on grow th of the Pscific oyster Crasostres. gigas reared in contrasting natural enviroments. Mo. Ecol. 11, 1499-1514.

Gus, X., Debrosse, G.A. and Allen, S.K.Jr.,1996. All triploid oysters (Crassostres gigss Thunberg) produced by mating tetraploids and diploids, Aquaculture, 142 : 149-161.

Kamermars P, T Galley, P Boudry, J Fuentes, H MeCombie, F M. Batists, A Blsnco, L Dominguez, F Cornette, L Pincot, 8. A Besumont (2013). Blus musse' hatehery technology in Europe. In: Advances in aquaculture hatehery technology. Woodhead Publishing Cambröge pp 339-373

Lapègue S., P. Boudry and P. Goulletquer (2008) Pacific cupped oyster - Crassostres gigas. Genimpact final scientific report.

Nell JA, Perkins B (2005) Studies on triploid oysters in Austra is: farming potential of all-triploid Pacific oysters Crassostrea gigss (Thunberg), in Port Stephens, New South Wales, Australis. Aquac $R=36: 530-536$

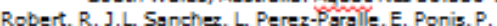
Kamermars, M. O'Mahoney (2612) Aglimpse of the molluse industry in Europe. Aqusculture Europe 38: 5

Stanley, J. G., H. Hidu and S. K. Allen, Jr. 1984. Grow th of American oysters incressed by polyploidy induced by blocking meiosis I but not meicsis If. Aquaculture 37 : 147-155.

\section{Nawoord}

In deze factsheet hebben we getracht een zo compleet mogelijk overzicht te geven van de huidige stand van zaken rondom triploide oesters. Echter de ontwikkelingen gaan snel, Topende onderzoken kunnen nieuwe inzichten geven. Het is belangrijk deze nieuwe ontwikkelingen te stimuleren en te blijven volgen.

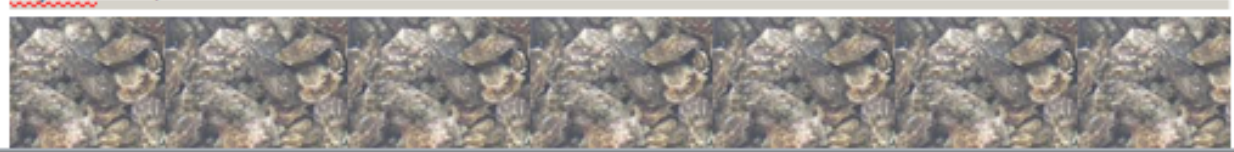




\section{Bijlage 2 Begeleiding OesterKweek eXperimenten (BOKX)}

Eind maart 2016 heeft I MARES een convenant gesloten met o.a. de Nederlandse Oestervereniging. In het kader daarvan is het project Begeleiding OesterKweek eXperimenten (BOKX) gestart en een werkplan opgesteld. Onderdeel daarvan is monitoring ten behoeve van vergunning voor off-bottom experimenten in sublitoraal van de Kom van de Oosterschelde. Dit betreft:

a. IMARES rapporteert het relatieve verschil in scheepsbewegingen en verbruik van gasolie tussen off-bottom kweek en bodemcultuur. Kwekers leveren gegevens aan. IMARES zal zorgdragen voor validatie van de gegevens door een vergelijking met informatie uit andere landen uit te voeren. De resultaten zullen worden teruggekoppeld aan de werkgroep off-bottom oesterteelt.

b. Voor de aanwezigheid van beschermde vogelsoorten op en nabij de experimenten in vergelijking met aanwezigheid op bodempercelen wordt een identificatie protocol opgesteld. Ook zal instructie aan boord plaatsvinden door I MARES medewerkers. Daarnaast zal I MARES tellingen uitvoeren op dagen dat de kwekers wel en niet aan het werk zijn. De resultaten zullen worden teruggekoppeld aan de werkgroep off-bottom oesterteelt. De onderzoeksvraag betreft: Is er verschil in aanwezigheid van beschermde vogelsoorten op en nabij de experimenten tijdens het uitvoeren van werkzaamheden in vergelijking met aanwezigheid van vogels op bodempercelen bij afwezigheid van werkzaamheden?

c. Een systematische monitoring van de groei en sterfte van een groep uniforme oesters die op verschillende plaatsen zijn uitgezet kan een beeld geven van het succes van off-bottom teelt in vergelijking met bodemcultuur. IMARES kan voor de monstername een protocol voor de kwekers opstellen en de monsters van off-bottom teelt en bodemcultuur analyseren. $\mathrm{Na}$ iedere monstername kunnen de resultaten worden teruggekoppeld aan de werkgroep off-bottom oesterteelt.

Indien de vergunning voor de experimenten in het litoraal wordt verleend, zal de monitoring daarvan ook worden opgenomen. Dit betreft dan naast bovengenoemde metingen ook onderzoek naar consequenties van tafels met zakken en lijnen met mandjes met betrekking tot 'lichtinval' en 'schaduwwerking' (verandering bodemdiatomeeën) en 'leefgebied en soorten' (verandering slibgehalte). Ook worden, tijdens veldbezoeken, de aanwezige predatoren van oesters in kaart gebracht, dan wel ter identificatie meegenomen naar het laboratorium. 


\section{Bijlage 3 Voorkomen vogels op locatie 640}

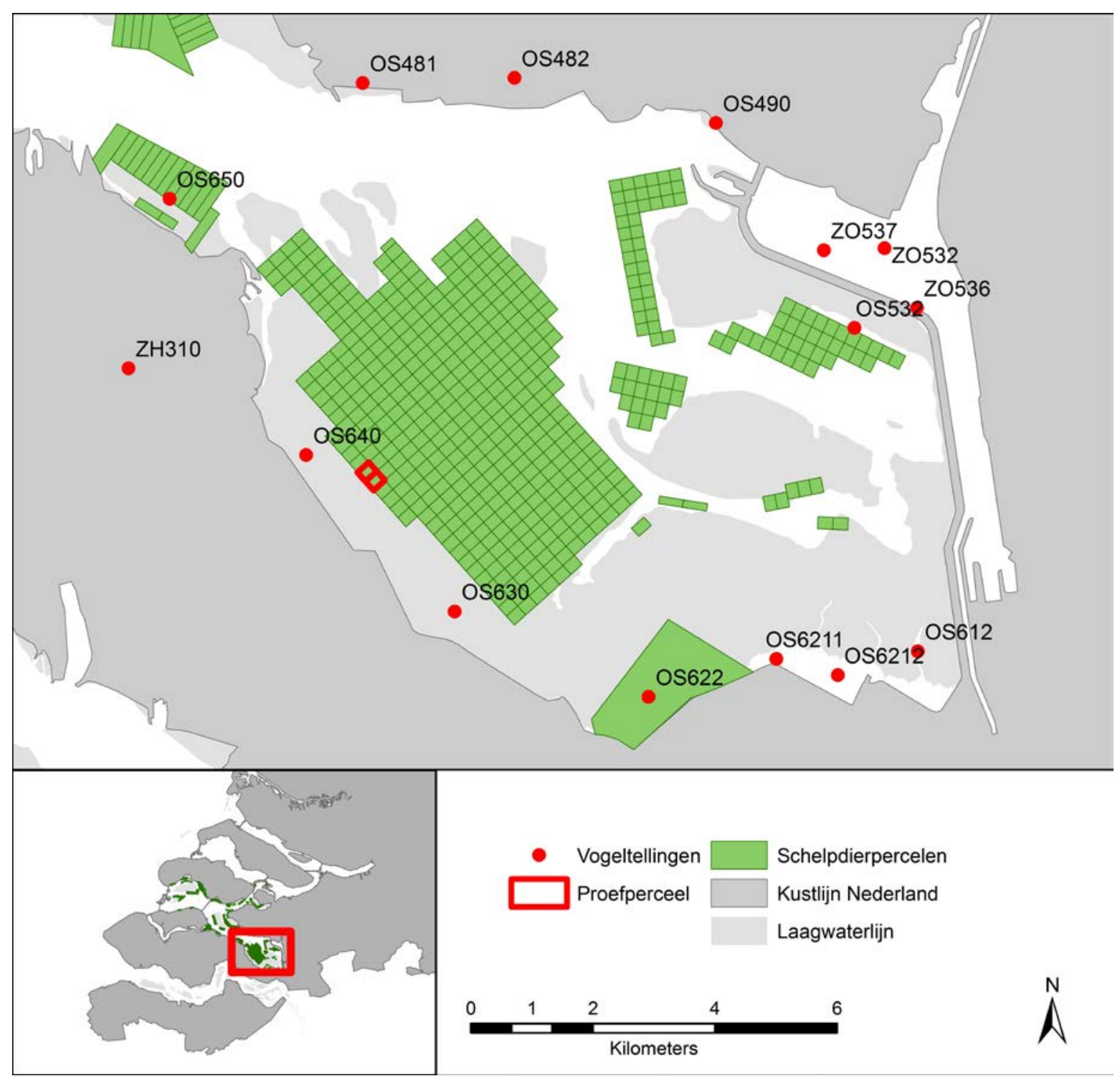

Litorale oesterpercelen Yerseke Bank 74 en 75 (rode kaders rond groene percelen) in de Kom van de Oosterschelde waar de oesterkweek experimenten gepland zijn en locatie RWS telpunt OS640.

RWS tellingen periode 2005 tot en met 2014. 


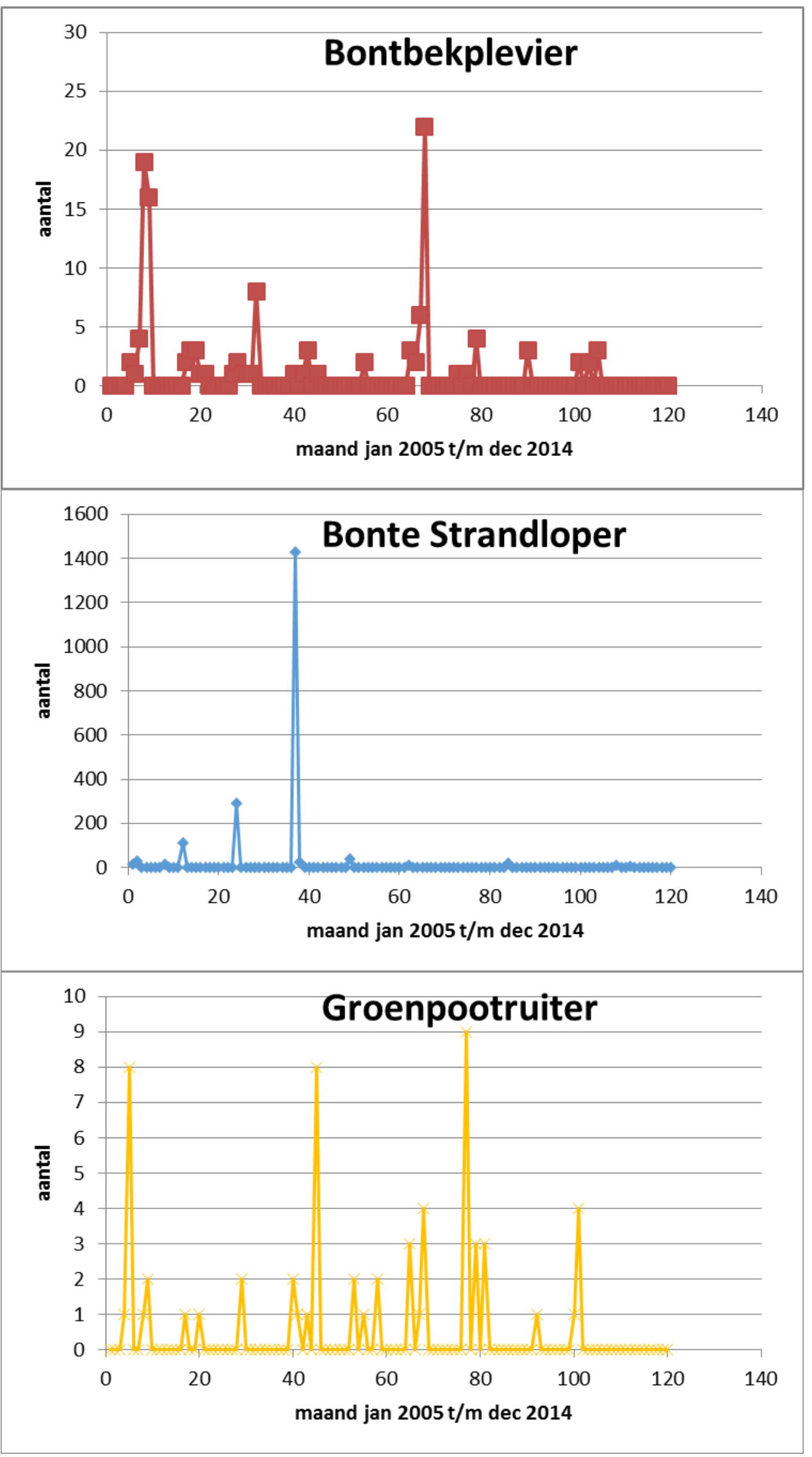



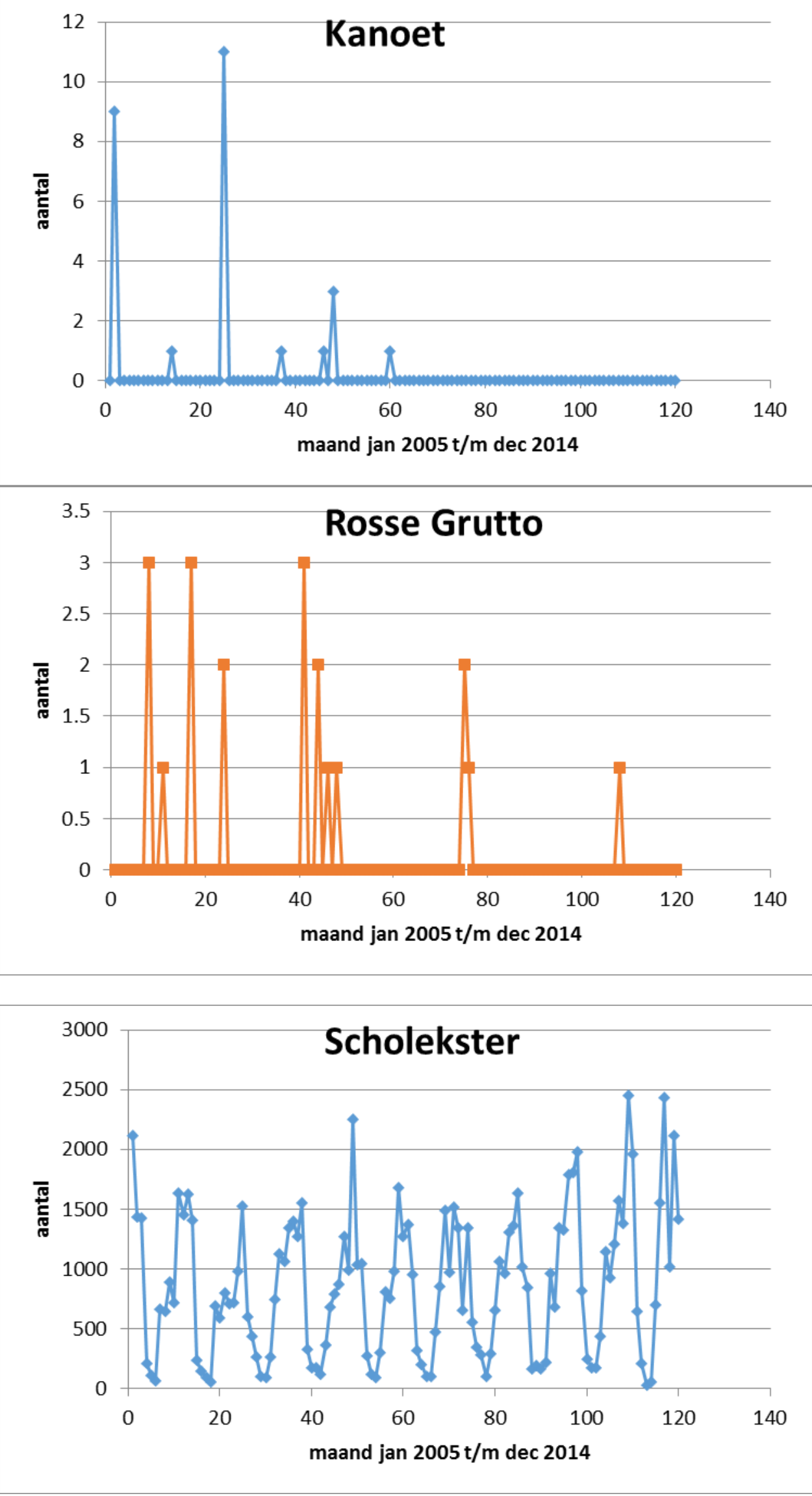

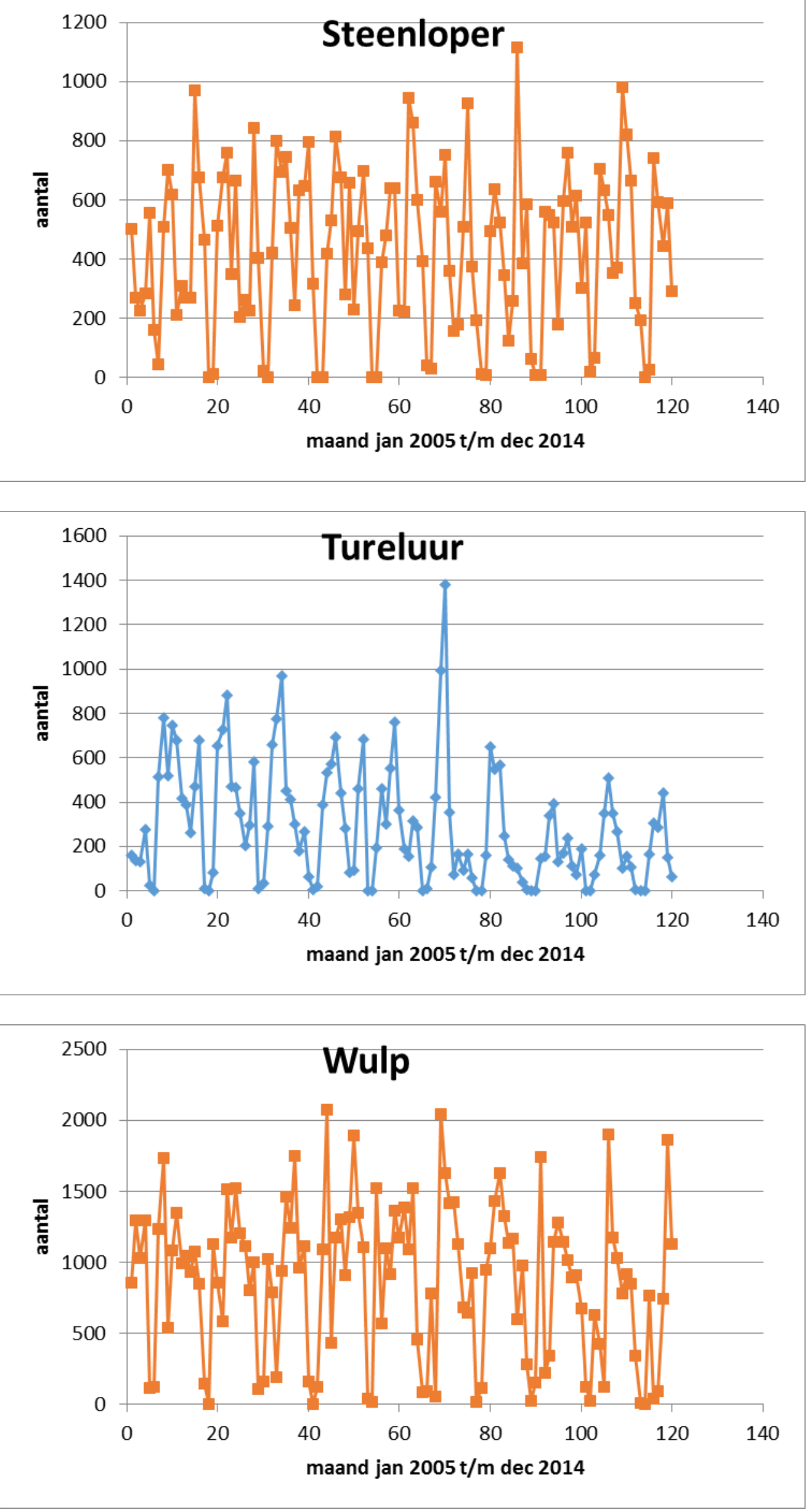


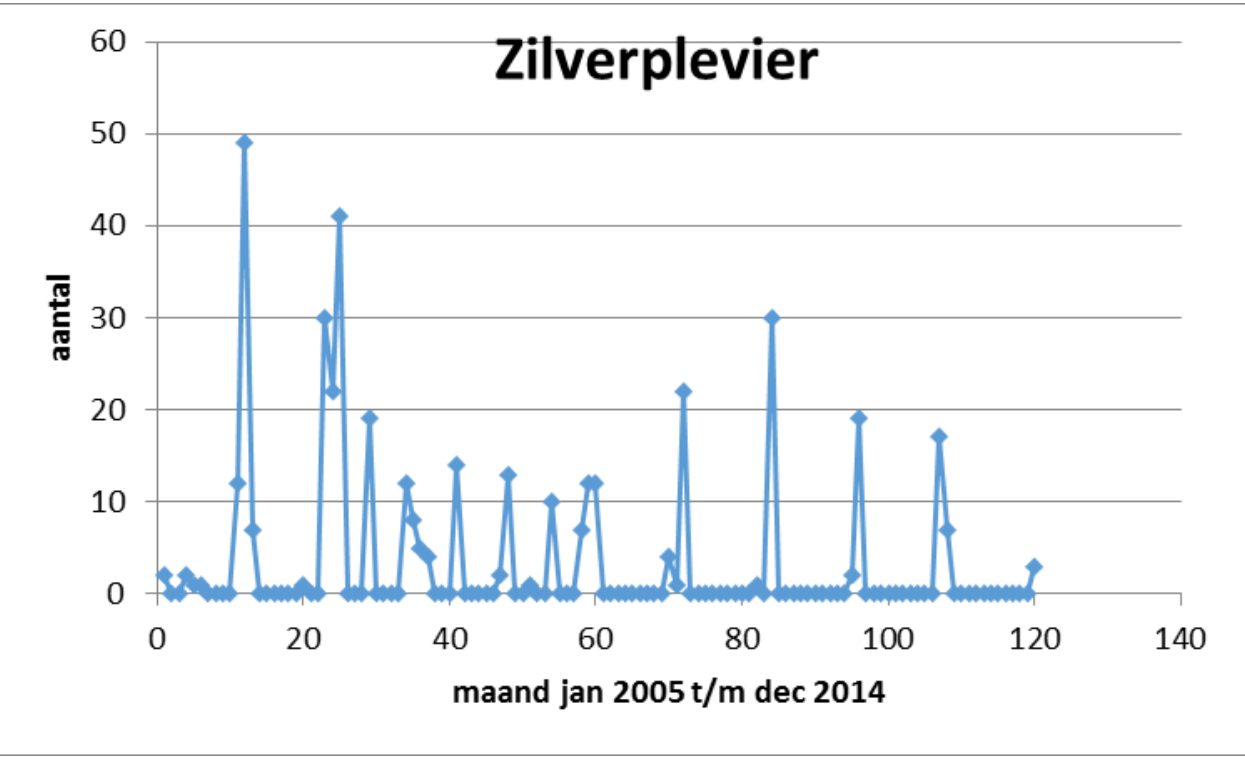


Wageningen Marine Research

T: +31 (0)317480900

E: marine-research@wur.nl

www.wur.nl/marine-research

Visitors address

- Ankerpark 27, 1781 AG Den Helder

- Korringaweg 5, 4401 NT Yerseke

- Haringkade 1, 1976 CP IJ muiden
Wageningen Marine Research is the Netherlands research institute established to provide the scientific support that is essential for developing policies and innovation in respect of the marine environment, fishery activities, aquaculture and the maritime sector.

Wageningen University \& Research is specialised in the domain of healthy food and living environment.

\section{The Wageningen Marine Research vision:}

'To explore the potential of marine nature to improve the quality of life.'

\section{The Wageningen Marine Research mission}

- To conduct research with the aim of acquiring knowledge and offering advice on the sustainable management and use of marine and coastal areas.

- Wageningen Marine Research is an independent, leading scientific research institute.

Wageningen Marine Research is part of the international knowledge organisation Wageningen UR (University \& Research centre). Within Wageningen UR, nine specialised research institutes of Stichting Wageningen Research (a Foundation) have joined forces with Wageningen University to help answer the most important questions in the domain of healthy food and living environment. 